\title{
FastCAT accelerates absolute quantification of proteins by using multiple short non-purified chimeric standards
}

Ignacy Rzagalinski ${ }^{1}$, Aliona Bogdanova ${ }^{1}$, Bharath Kumar Raghuraman ${ }^{1}$, Eric R. Geertsma ${ }^{1}$, Lena Hersemann$^{1}$, Tjalf Ziemssen ${ }^{2}$, Andrej Shevchenko ${ }^{1 *}$

${ }^{1}$ Max Planck Institute of Molecular Cell Biology and Genetics, 01307 Dresden, Germany

${ }^{2}$ Center of Clinical Neuroscience, Department of Neurology, University Hospital Carl Gustav Carus, Technical University of Dresden, 01307 Dresden, Germany

*Corresponding author:

Dr. Andrej Shevchenko

Tel: +493512102615

Email: shevchenko@mpi-cbg.de 


\section{ABSTRACT}

Absolute (molar) quantification of proteins provides the analytical rationale for system-level modelling of diverse molecular mechanisms. FastCAT method employs multiple short $(<50$ $\mathrm{kDa})$ stable-isotope labeled chimeric proteins (CPs) composed of concatenated quantotypic (Q) peptides representing the quantified proteins. Each $\mathrm{CP}$ also comprises scrambled sequences of reference (R-) peptides that relate its abundance to a single protein standard (BSA). FastCAT not only alleviates the need in purifying CP or using SDS-PAGE, but also improves the accuracy, precision and dynamic range of the absolute quantifications by grouping Q-peptides according to the expected abundance of target proteins. We benchmarked FastCAT against the reference method of MS Western and tested it in the direct molar quantifications of neurological markers in human cerebrospinal fluid at the low $\mathrm{ng} / \mathrm{mL}$ level.

Keywords: absolute quantification of proteins; MS Western; QconCAT; targeted quantitative proteomics; cerebrospinal fluid; neurodegeneration; neuroinflammation 


\section{INTRODUCTION}

The role of absolute (molar) quantification of proteins is multifaceted. It determines stoichiometric ratios within molecular assemblies and metabolic pathways ${ }^{1}$ and relates them to non-proteinous compounds e.g. co-factors, lipids or metabolites; provides reference values and ranges for diagnostically important proteins in liquid and solid biopsies. ${ }^{2}$ Last but not least, it estimates the expression levels in cells and tissues serving as a quantitative denominator common to all omics sciences. In contrast to popular immunodetection methods (ELISA or Western blotting), ${ }^{3}$ mass spectrometry quantifies proteins by comparing the abundance of endogenous quantotypic peptides with corresponding synthetic peptides having with exactly known concentration. Protein concentration is then inferred from the concentrations of quantotypic peptides. However, protein and peptide properties are unique and may vary significantly. ${ }^{4}$ To support clinical diagnostics, it is necessary to quantify a selection of diseaserelated proteins whose molar abundance differs by several orders of magnitude. It is therefore not surprising that, in contrast to relative quantification, absolute quantitative methods lack generality and unification.

Methods for absolute quantification of proteins (reviewed $\mathrm{in}^{5}$ ) rely upon different types of internal standards, including (but not limited to) synthetic peptides (e.g. AQUA) ${ }^{6}$; full-length or partial protein sequences (e.g. $\mathrm{PSAQ}^{7}$ and $\mathrm{QPrEST}^{8}$, respectively) and also chimeric proteins composed of concatenated proteotypic peptides from many different proteins (QconCAT) ${ }^{9}$ (reviewed in $\left.^{10-13}\right)$. Because of the advances in gene synthesis, QconCAT offers several appealing qualities e.g. ease of multiplexing, support of targeted and mid- to large-scale quantification applied to individual proteins and complexes, biochemical pathways ${ }^{14}$ or clinically relevant selection of proteins. ${ }^{15,16}$ QconCAT chimeras are expressed in E.coli, enriched and purified by affinity chromatography and their stock concentration is determined 
by amino acid analysis or some protein assays ${ }^{17}$. Alternatively, an additional (secondary) peptide concatenated standard (PCS) was used to quantitatively characterize multiple primary PCSs. ${ }^{18}$ Also, a QconCAT chimera could include the sequence of [Glu1]-Fibrinopeptide $\mathrm{B}^{19}$ that enabled its one-peptide quantification, although synthetic peptide standards should be used with caution. ${ }^{20}$

By using GeLC-MS/MS, MS Western workflow alleviated the need in making and standardizing a purified stock of CP. Also, CP standard was designed such that it included not only quantotypic (Q-)peptides, but also several reference (R-)peptides. ${ }^{21}$ The bands of $\mathrm{CP}$ and of reference protein (BSA) were co-digested with gel slabs containing target proteins and the recovered peptides analyzed by LC-MS/MS. The abundance of CP was referenced to exactly known amount of BSA (available as NIST certified standard) and then the abundance of the target protein was calculated from the abundance of $\mathrm{CP}$ assuming that its full cleavage produced proteotypic peptides in the equimolar amount. MS Western quantification was based on the concordant values (CV <10 \%) obtained from multiple (usually 2 to 4) Q-peptides per each protein of interest. $^{22,23}$

Because of the use of SDS, GeLC-MS/MS helped to detect more membrane proteins. SDS PAGE also alleviated the need in purifying CP, yet it limited the analyses throughput. Although collecting hundreds of quantotypic peptides in large (up to $290 \mathrm{kDa}$ ) chimeras is appealing, it is practically inflexible because new proteins and / or peptides could not be added at will. Furthermore, the yielded Q-peptides are strictly equimolar, which hampers the quantification of proteins having drastically (more than 100-fold) different abundance. This, however, is often required for monitoring protein biomarkers. ${ }^{24}$

Here, we report on FastCAT (Fast-track QconCAT) method that preserves the accuracy and consistency of MS Western quantification, yet is faster, more flexible and easier to use particularly in translational proteomics applications. In contrast to MS Western, FastCAT 
workflow relies on the parallel use of many relatively short $(<50 \mathrm{kDa})$ non-purified CPs that comprise Q-peptides for the target proteins, but also scrambled R-peptides to reference the CP concentrations to the same BSA standard.

\section{EXPERIMENTAL SECTION}

\section{Chemicals and reagents}

LC-MS grade solvents (water, acetonitrile and isopropanol), formic acid (FA) and trifluoroacetic acid (TFA) were purchased from Fisher Scientific (Waltham, MA) or Merck (Darmstadt, Germany). Trypsin and trypsin/Lys-C proteases (MS grade) were from Promega (Madison, WI); RapiGest detergent from Waters (Eschborn, Germany); other common chemicals from Sigma-Aldrich (Munich, Germany). Polyacrylamide gradient gels (4-20 \%) were from Serva Electrophoresis GmbH (Heidelberg, Germany). Protein standards: glycogen phosphorylase (GP), alcohol dehydrogenase (ADH), enolase (ENO) and ubiquitin (UBI) were purchased as a lyophilized powder from Sigma-Aldrich. Reference protein standard (BSA, Pierce grade, in ampoules) was from Thermo Fisher Scientific (Waltham, MA). Isotopically labeled amino acids $\left({ }^{13} \mathrm{C}_{6},{ }^{15} \mathrm{~N}_{4}\right.$-L-arginine (R) and ${ }^{13} \mathrm{C}_{6}$-L-lysine $\left.(\mathrm{K})\right)$ were purchased from Silantes GmbH (Munich, Germany).

\section{Design and expression of chimeric protein standards}

In total, six CP standards of different molecular weights (MW) were designed and expressed. General scheme of CP design is presented in Figure S1, while other details including MWs, isotopic enrichment labeling efficiency and full-length sequences are in Table S4. DNA sequences encoding CPs were codon-optimized for E.coli by Genscript on-line tool and 
synthesized by Genscript. CPs were produced using pET backbone (Novagenn) and E.coli BL21 (DE3) (argA lysA) strain auxotrophic for arginine and lysine supplemented with ${ }^{13} \mathrm{C}_{6},{ }^{15} \mathrm{~N}_{4}$-L-arginine and ${ }^{13} \mathrm{C}_{6}$-L-lysine as described. ${ }^{21}$

\section{Sample preparation for proteomics analyses}

Polyacrylamide gels were stained with Coomassie CBB R250 and gel slabs corresponding to the targeted range of MW were excised. In-gel digestion with trypsin was performed as previously reported ${ }^{21}$ with enzyme-to-substrate ratio of 1:50. E.coli background with spiked 4 standard proteins was on-pellet digested with trypsin (1:20) after protein precipitation with isopropyl alcohol according to the previously described protocol. ${ }^{25}$ Aliquots of cerebrospinal fluid (CSF) of $20 \mu \mathrm{L}$ volume were in-solution digested with trypsin/Lys-C protease mix (1:20) in the presence of RapiGest (Waters) detergent. ${ }^{26} \mathrm{CSF}$ samples were obtained from patients diagnosed with multiple sclerosis and stored as freshly frozen aliquots. All patients gave their prior written consent. The study was approved by the institutional review board of the University Hospital Dresden (EK348092014).

\section{LC-MS/MS analyses}

LC-MS/MS was performed on a Q Exactive HF (Thermo Scientific, Germany) hybrid tandem mass spectrometer coupled with Eksigent 400 nanoLC system (Sciex, Germany) using the Nanospray Flex source (Thermo Fisher Scientific, Germany). Protein digests were loaded onto a trap column for 5 min at $7 \mu \mathrm{L} / \mathrm{min}$ and separated on the Acclaim PepMap 100 column (C18, $3 \mu \mathrm{m}, 75 \mathrm{um} \times 150 \mathrm{~mm})$ using $120 \mathrm{~min}$ gradients $(5-45 \% \mathrm{~B})$ at $300 \mathrm{~nL} / \mathrm{min}$ in data-dependent acquisition (DDA) or parallel reaction monitoring (PRM) modes (as specified). DDA and PRM methods consisted of MS1 scan from $m / z 350$ to 1700 with automatic gain control (AGC) target value of $3 \times 10^{6}$; maximum injection time (IT) of $60 \mathrm{~ms}$ and targeted mass resolution $\mathrm{R}_{m / z=200}$ of 
60,000. Top-12 DDA method employed the precursor isolation window of $1.6 \mathrm{Th}$; AGC of $1 \times 10^{5}$; maximum IT of $50 \mathrm{~ms} ; \mathrm{R}_{m / z=200}$ of 15,000 ; normalized collision energy (NCE) of $25 \%$ and dynamic exclusion of $30 \mathrm{~s}$. The scheduled PRM method acquired MS/MS using 10-min retention time (RT) windows with the inclusion list of 97 precursors; precursor isolation window of $1.6 \mathrm{Th}$; AGC of $1 \times 10^{6}$; a maximum IT of $80 \mathrm{~ms}$; $\mathrm{R}_{m / z=200}$ of 30,000 and NCE of $25 \%$.

\section{Data processing and analysis}

Raw LC-MS/MS data from DDA experiments were processed by Progenesis LC-MS v.4.1 (Nonlinear Dynamics, UK) software for RT alignment, peak picking and extracting the peptide features. To match peptides to target proteins, MS/MS spectra were searched by Mascot v.2.2.04 software (Matrix Science, London, UK) against a customized database containing sequences of all target proteins and relevant (either E.coli or human) background proteome. Precursor mass tolerance of $5 \mathrm{ppm}$; fragment mass tolerance of $0.03 \mathrm{Da}$; fixed modification: carbamidomethyl (C); variable modifications: acetyl (protein N-terminus) and oxidation (M); labels: ${ }^{13} \mathrm{C}_{6}(\mathrm{~K})$ and ${ }^{13} \mathrm{C}_{6}{ }^{15} \mathrm{~N}_{4}(\mathrm{R})$, cleavage specificity: trypsin with up to 2 missed cleavages allowed). All PRM data sets were analyzed with Skyline 21.1.0.278 software. ${ }^{27}$ Peak integration was inspected manually. Mass transitions in labeled and unlabeled peptides and matching retention time and peak boundaries were confirmed the peptide identities. A minimum of five transitions were required for the correct identification of the targeted peptides. In addition, the comparison of the measured fragment spectrum to the in-silico Prosit-derived ${ }^{28}$ library spectrum by the normalized spectral contrast angle was used that resulted in the library dot product (dotp) correlation values of 0.87 or higher. 


\section{RESULTS AND DISCUSSION}

\section{Using crude CP standards for protein quantification}

Trypsin cleavage of purified CP produces Q- and R-peptides in a strictly equimolar concentration. ${ }^{21,29,30}$ However, in crude extracts the concentration balance between individual Q-peptides could be affected by non-proportional contribution of products of intra-cell proteolysis of $\mathrm{CP}$ and/or incomplete translation of the $\mathrm{CP}$ gene. Also, despite $\mathrm{CP}$ are highly expressed, ${ }^{21}$ their purification reduces the load of an expression host (E.coli) proteins and their contribution to overall compositional complexity of the analyzed sample is unclear.

Therefore, we set out to test under what conditions the full-length CP standards could be employed with no further purification. To this end, we selected three CP standards spanning a wide MW range (CP01 265 kDa, CP02 79kDa and CP03 42 kDa) (Supplementary Table S4). We loaded protein extracts onto 1D SDS-PAGE, excised the CP bands, sliced the entire gel slab in several MW ranges below the band of CPs and analyzed them separately by GeLCMS/MS (Figure 1). We observed that the relative abundance of Q-peptides depends on molecular weights of the full-length $\mathrm{CP}$ and its truncated forms, but also on the peptide location within the $\mathrm{CP}$ sequence. In $265 \mathrm{kDa} \mathrm{CP}$ peptides located closer to its $\mathrm{N}$-terminus were overrepresented and constituted 40 to $80 \%$ of total peptide abundances (Figure 1A). We also observed the same trend for the middle-size CP with 20 to $40 \%$ fraction of truncated forms and slight prevalence of N-terminally located peptides (Figure 1B). However, in the shortest (42 $\mathrm{kDa}$ ) $\mathrm{CP}$ the contribution of truncated forms was minor (ca 10-15\%) and independent of peptides location (Figure 1C).

Because of lower expression and high fraction of proteoforms having incomplete sequence truncated elsewhere at the $\mathrm{C}$-terminal side, larger $\mathrm{CP}$ required extensive purification. Shorter CPs (less than ca. $50 \mathrm{kDa}$ ) are highly expressed with much lower fraction of truncated 
forms having no location prevalence. Consistently, the relative abundances of Q-peptides at different locations within the CP sequence (N-terminal vs. middle ("M") vs. C-terminal) in the purified $\mathrm{CP}$ and non-purified $\mathrm{CP}$ (CP band together with truncation products) were very close (Figure 1E). Therefore, we concluded that spiking the total E.coli extract without isolating the full-length CP should not bias the quantification.

Since short CPs are highly expressed in E.coli they are usually diluted more than 100fold down to $c a .1 \mu \mathrm{M}$ concentration. Therefore, we wondered if adding the extract of E.coli containing an appropriate amount of a non-purified CP elevated protein background. For reliable comparison, we mixed a volume of metabolically labeled extract containing typical working amounts of $\mathrm{CP}$ ( $\mathrm{ca} .100 \mathrm{fmol})$ with an equivalent volume of unlabeled extract containing $c a .500 \mathrm{ng}$ of total protein. We then compared relative abundances of labeled and unlabeled forms of nine major E.coli proteins (Table S1) and concluded that adding an extract with unpurified CP increased protein background by as little as $2 \%$ (Figure S2).

We therefore concluded that short $\sim 50 \mathrm{kDa}$ CPs could be spiked into quantified samples as total (crude) E.coli lysates with no prior purification. With that size, they would be typically encoding for 25 to 30 Q-peptides and 3 to 5 R-peptides within a typical CP construct. ${ }^{21}$

\section{FastCAT workflow: the concept and its validation}

We reasoned that, by employing short non-purified $\mathrm{CP}$, a targeted absolute quantification workflow (termed FastCAT for Fast-track QconCAT) could significantly accelerate the analysis. Besides Q-peptides used to quantify target proteins, a typical FastCAT construct contains multiple (usually 3 to 5) R-peptides used to determine the in-situ CP concentration by referencing it to the known amount of spiked-in BSA. Hence, FastCAT workflow requires neither CP purification (externally or by gels) nor an external determination 
of its concentration, while the multi-peptide quantification procedure is the same as in MS Western.

We cross-validated FastCAT by comparing it against MS Western. ${ }^{21}$ To this end, we prepared an approximately equimolar $(c a .1 \mu \mathrm{M})$ mixture of the 4 standard proteins (GP, UBI, $\mathrm{ADH}$ and $\mathrm{ENO}$ ) and spiked it (ca. $20 \mathrm{pmol}$ of each protein) into E.coli background (ca. $50 \mu \mathrm{g}$ of total protein). We determined their exact quantities by MS Western using $42 \mathrm{kDa}$ (CP03) as an internal standard. ${ }^{21}$ In parallel, we quantified them by FastCAT protocol using the same 42 $\mathrm{kDa}$ construct, but without 1D SDS-PAGE. Importantly, we did the quality check of the digestion completeness for both methods by comparing relative abundances of labeled Qpeptides in $\mathrm{CP} 03$ and corresponding unlabeled peptides in the endogenous proteins. The difference in protein quantities determined by FastCAT and MS Western were below $15 \%$ for all proteins (Table 1).

Since in FastCAT workflow CP was not purified, we additionally checked if the positioning of Q- and R-peptides within the $\mathrm{CP}$ backbone affected the quantification. To this end, we designed another CP standard, CP04, having the same Q-peptides as in CP03, but distributing the same five R-peptides (R1-R5) over the entire CP sequence compared to a single block of R-peptides at the C-terminus of CP03 (see Figure 2).

This experiment resulted in two major findings. Firstly, using CP03 and CP04 independently led to concordant quantification. With all R-peptides used for calculating CPs abundances, the quantities of target proteins differed by less than $15 \%$. Secondly, the quantification was practically unaffected by positioning of R-peptides. Indeed, using differentially positioned R-peptides (N (R1/R5) vs. "M" (R2) vs. C (R3/R4)) in CP04 led to the quantification of all target protein with $\mathrm{CV} c a .9 \%$ (Figure 2A). This minor variability could not be solely attributed to the different location of R-peptides. A similar value of CV ca. $7 \%$ 
was observed when target proteins were quantified using CP03 with similarly positioned Rpeptides (R1/R5 vs. R2 vs. R3/R4, all at C-terminus) as in CP04 (Figure 2B).

We therefore concluded that in the FastCAT workflow the design of $\mathrm{CP}$ and relative positioning of R-peptides have no major impact on the proteins quantification.

\section{Multiplexing of FastCAT}

Relatively short CP standards having the MW of 40 to $50 \mathrm{kDa}$ will typically comprise 20 to 30 Q-peptides. Considering that the robust protein quantification would require 3 to 5 peptides per each protein, one $\mathrm{CP}$ would enable the quantification of 5 to 8 individual proteins of, preferably, similar abundance. Hence, there is a need in multiplexing the FastCAT quantification capacity.

We therefore proposed to group proteotypic peptides into CPs according to the expected abundance of target proteins and then to use multiple CPs in parallel to cover the desired number of proteins (Figure 3). However, the abundance of different CPs should be referenced to the same spiked-in BSA standard. We achieved it by including reference peptides with the scrambled sequences $\left(\mathrm{R}_{\mathrm{s}}\right.$-peptides) ${ }^{31}$ that, nevertheless, elicit very similar response in MS1 spectra compared to corresponding native $\mathrm{R}_{\mathrm{n}}$-peptides. However, we reasoned that, for better sensitivity, the targeted analysis would require PRM also for quantifying CPs in the same LCMS/MS run. Therefore, for each $R_{n} / R_{s}$ peptides pair, we selected a representative combination of fragment ions that adequately reflected the peptides abundance ${ }^{32,33}$ and, hence, enable parallel quantification of multiple CPs.

To this end, we designed CP05 and CP06 proteins (see Supplementary Figure S3 for amino acid sequences and Figure S4 for the distributions of their truncated forms) containing 42 Q-peptides from 10 selected human proteins (these CPs were further used for the case study in the section below). They also comprised 10 R-peptides as 5 pairs of native $\left(\mathrm{R}_{\mathrm{n}}\right)$ and 
scrambled $\left(\mathrm{R}_{\mathrm{s}}\right)$ sequences. However, R-peptides were placed into $\mathrm{CP} 05$ and $\mathrm{CP} 06$ such that they contained 3 native plus 2 scrambled, and 2 native plus 3 scrambled R-peptides, respectively (Figure 4). To emulate the impact of protein background, we spiked these CPs in ca. $1 \mu \mathrm{M}$ concentration into a $20 \mu \mathrm{L}$ aliquot of human cerebrospinal fluid (CSF) and analyzed by the method of PRM.

For each $R_{n} / R_{s}$ peptide pair we compared the distribution of abundances of the most intense fragments within y- and b-ions (see Supplementary Figure S5 for MS2 spectra). Out of 5 pairs, three pairs produced very similar profiles, while two other pairs mismatched (Figure $5)$.

Next, we assessed the concordance of the in-situ PRM-based quantification of CPs using each $\mathrm{R}_{\mathrm{s}}$-peptide with the reference values obtained by $\mathrm{R}_{\mathrm{n}}$-peptides. To do this, we considered three quantification scenarios based on the selection of different combinations of fragment ions: Top1, Top3(y) and Top6(y,b) (as exemplified in Figure 5); and compared them to the values computed from the abundance of MS1-peaks (see Supplementary Table S2 for details ). As expected, the Top1 approach not only resulted in the highest error (>35\%) for the two mismatching $R_{n} / R_{s}$ (\#2 and \#3) pairs, but also revealed the highest overall (for all $R_{n} / R_{s}$ pairs) discordance with MS1 (Figure 6). In contrast, summing up the abundances of more fragments (in Top3(y) or Top6(y,b) scenarios) compensated minor differences in the fragmentation patterns of $R_{n} / R_{s}$-peptides. We note that for low resolution selected reaction monitoring (SRM) experiments, that cannot follow many transitions and using b-ions should rather be avoided, ${ }^{34}$ the Top3(y) approach could be the most practical compromise.

However, for PRM-based quantification summing up the abundance of the 6 most abundant $y$ - and b-fragment ions will lead to the most consistent estimates with lower than 20 $\%$ difference to MS1-based determinations (Figure 6). Eventually, within the two CPs the 
relative abundances of all used (both native and scrambled) R-peptides measured via Top6(y,b) fragments differed by less than 5\% (Supplementary Figure S6).

We therefore concluded that multiplexing of FastCAT workflow could be achieved by using several CPs comprising multiple scrambled peptides of BSA. Quantities of individual CPs could be referenced to the same BSA standard by PRM analysis that relies on the summation of the six most intense $y$ - and b-ions for each $R_{s}$ (in the $C P$ ) and $R_{n}$ (in BSA standard) peptide pair.

\section{Case study: absolute quantification of neurological protein markers in the human CSF}

Multiple sclerosis is an immune-mediated demyelinating and neurodegenerative disease of the central nervous system (CNS), which is usually accompanied by blood-brain barrier disruption, infiltration of immune cells into the CNS, and nerve fibers demyelination and axonal loss. ${ }^{35}$ It alters the CSF proteome and monitoring the levels of protein markers by common clinical chemistry methods (e.g. ELISA) aids in its molecular diagnostics. ${ }^{36}$ However, these methods suffer from low concordance, limited scope and substantial costs. Here we employed FastCAT to determine the molar concentrations of a selection of protein markers having a broad range of physicochemical properties, molar abundance and magnitude of response towards the disease.

We obtained 11 samples of CSF from five (four female and one male) 30 to 61 years of age patients that were diagnosed with relapsing-remitting multiple sclerosis. CSF was drawn from each patient at two time points: the first puncture was performed during the initial diagnostics while the second (and, for one patient, also the third) puncture was performed $c a .2$ years later prior to a planned treatment switch to validate that no significant inflammation and neurodestruction occurred. Based on clinical indications, ten protein markers were selected out of $c a .700$ proteins detected in a pooled CSF sample in the course of preliminary experiment. 
Those included two major lipoproteins (APOE and APOD); inflammation-related glycoproteins (AACT, ZAG and LRG1); markers of axonal (CNTN1) and synaptic (NPTX1 and VGF) related disorders; a member of the granins family (SCG1) and, finally, a neuroinflammatory marker (CH3L1) typically increased in patients with multiple sclerosis. ${ }^{37,38}$ We then selected 42 Qpeptides and assembled them in CP05 and CP06 (also mentioned above) according to the arbitrary abundance of target proteins.

The method precision was evaluated by processing and analyzing the pooled CSF sample in triplicate (Figure S7). For both CP and target proteins peptide and protein levels the median coefficient of variation was below $6 \%$. Importantly, peptides originating from the same protein led to their highly concordant quantification as exemplified by median CV of $c a .12 \%$.

The median values and the ranges of variation of target proteins are reported in Table 2 , which also include Q-peptides and the estimates of quantification concordance for the independent quantification by multiple peptides. Concentration ranges determined by FastCAT showed particularly good concordance with previously reported SRM and PRM determinations. For instance, similar concentration ranges were obtained for APOE, ${ }^{39,40} \mathrm{AACT},{ }^{41} \mathrm{SCG}{ }^{42}$ and $\mathrm{CH} 3 \mathrm{~L} 1{ }^{43}$ At the same time, the concordance with ELISA measurements was limited for both FastCAT and published SRM/PRM values. While ranges determined by ELISA for AACT, ${ }^{44}$ LRG1, ${ }^{45,46} \mathrm{CH} 3 \mathrm{~L}^{43,47,48}$ and $\mathrm{CNTN} 1{ }^{44}$ were close to FastCAT, levels for both apolipoproteins were discordant (yet, again, concordant with SRM/PRM). ${ }^{49-52}$ This, however, is consistent with the previously described discrepancies between ELISA and mass spectrometry. ${ }^{39}$ Molar concentration of ZAG, VGF and NPTX1 was not reported previously.

Concentrations determined in individual patients (Supplementary Table S3) were stable over the two-year period of treatment and, except one patient, they clustered together at the PCA plot (supplementary Figure S8). PCA plot singled out one female patient presumably 
because of her higher age, although the proteins concentration in both of her biopsies were concordant.

Several trends (e.g. increase in APOD and ZAG; decrease in NPTX1) corroborated previous reports. ${ }^{53-55}$ At the same time, there was no consistent change in the levels of prospective multiple sclerosis markers SCG1 and LRG1. ${ }^{46,56}$

Notably, the amount of spiked CP05 standard was ca 10-fold higher than of CP06 (309 fmol/column vs. $33 \mathrm{fmol} /$ column, respectively). For better consistency, BSA was spiked at some intermediate amount (100 fmol/column). In this way, PRM covered 100-fold range of concentrations from $c a .20 \mathrm{ng} / \mathrm{mL}$ for CH3L1 to $c a .2000 \mathrm{ng} / \mathrm{mL}$ for APOD without breaking inter-peptide quantification consistency. Considering the observed signal-to-noise ratios, PRM was not close to the limit of detection and, in principle, should allow us to reach 10-fold higher sensitivity if the appropriate amount of yet another CP standard is spiked into CSF sample. Taken together, we demonstrated that FastCAT supported direct molar quantification of 10 neurological protein markers is CSF at the low $\mathrm{ng} / \mathrm{mL}$ levels, better that 100 -fold dynamic range and good $(\mathrm{CV}<20 \%)$ inter-peptide quantification consistency based on two to four peptides per each protein.

\section{CONCLUSION AND PERSPECTIVES}

Absolute quantification of proteins offers heavily missing data on the concentrations (or molar abundances) of proteins in cells, tissues and biofluids. FastCAT workflow combines flexibility and ease of use of peptide-based quantitation. It relies on a large number of peptide standards having the exactly known equimolar concentration that are produced in-situ and quantified in the same LC-MS/MS run together with peptides from target proteins. Controlled 
scrambling of R-peptides together with alternative strategies in metabolic labeling offer practically infinite capabilities for multiplexing. The quantification could be organized in a "modular" fashion by combining CPs of the desired composition and concentration.

In the future, it might be practical to set up a repository of plasmids encoding CPs and make them publicly available at some nominal fees. This will improve the analyses consistency and, eventually, brining absolute quantification closer to clinical chemistry requirements. While throughput of LC-MS/MS quantification could hardly compete with ELISA, its accuracy, independence of antibodies, quantification transparency and analytical flexibility, including compatibility with major protocols for biochemical enrichment and robotic sample preparation, might be appealing in many translational applications. We also argue that the interested laboratories should work together towards benchmarking and validating the absolute quantification methods by ring trials that are now common in neighboring omics fields, e.g. lipidomics. ${ }^{57}$

\section{ACKNOWLEDGMENTS}

Work in Shevchenko group is supported by Max Planck Society. The authors are grateful for other group members for expert technical support and useful discussions. 


\section{REFERENCES}

(1) Bantscheff, M.; Lemeer, S.; Savitski, M. M.; Kuster, B. Quantitative Mass Spectrometry in Proteomics: Critical Review Update from 2007 to the Present. Anal. Bioanal. Chem. 2012, 404 (4), 939-965. https://doi.org/10.1007/s00216-012-6203-4.

(2) Füzéry, A. K.; Levin, J.; Chan, M. M.; Chan, D. W. Translation of Proteomic Biomarkers into FDA Approved Cancer Diagnostics: Issues and Challenges. Clin. Proteomics 2013, 10 (1). https://doi.org/10.1186/1559-0275-10-13.

(3) Ren, A. H.; Diamandis, E. P.; Kulasingam, V. Uncovering the Depths of the Human Proteome: Antibody-Based Technologies for Ultrasensitive Multiplexed Protein Detection and Quantification. Mol. Cell. Proteomics 2021, 20, 100155. https://doi.org/10.1016/J.MCPRO.2021.100155.

(4) Boja, E. S.; Fehniger, T. E.; Baker, M. S.; Marko-Varga, G.; Rodriguez, H. Analytical Validation Considerations of Multiplex Mass-Spectrometry-Based Proteomic Platforms for Measuring Protein Biomarkers. J. Proteome Res. 2014, 13 (12), 5325-5332. https://doi.org/10.1021/pr500753r.

(5) Calderón-Celis, F.; Encinar, J. R.; Sanz-Medel, A. Standardization Approaches in Absolute Quantitative Proteomics with Mass Spectrometry. Mass Spectrom. Rev. 2018, 37 (6), 715-737. https://doi.org/10.1002/mas.21542.

(6) Gerber, S. A.; Rush, J.; Stemman, O.; Kirschner, M. W.; Gygi, S. P. Absolute Quantification of Proteins and Phosphoproteins from Cell Lysates by Tandem MS. Proc. Natl. Acad. Sci. U. S. A. 2003, $100 \quad$ (12), 6940-6945. https://doi.org/10.1073/pnas.0832254100.

(7) Picard, G.; Lebert, D.; Louwagie, M.; Adrait, A.; Huillet, C.; Vandenesch, F.; Bruley, C.; Garin, J.; Jaquinod, M.; Brun, V. PSAQ ${ }^{\mathrm{TM}}$ Standards for Accurate MS-Based Quantification of Proteins: From the Concept to Biomedical Applications. J. Mass Spectrom. 2012, 47 (10), 1353-1363. https://doi.org/10.1002/jms.3106.

(8) Zeiler, M.; Straube, W. L.; Lundberg, E.; Uhlen, M.; Mann, M. A Protein Epitope Signature Tag (PrEST) Library Allows SILAC-Based Absolute Quantification and Multiplexed Determination of Protein Copy Numbers in Cell Lines. Mol. Cell. Proteomics 2012, 11 (3), O111.009613. https://doi.org/10.1074/mcp.O111.009613.

(9) Beynon, R. J.; Doherty, M. K.; Pratt, J. M.; Gaskell, S. J. Multiplexed Absolute Quantification in Proteomics Using Artificial QCAT Proteins of Concatenated Signature Peptides. Nat. Methods 2005, 2 (8), 587-589. https://doi.org/10.1038/nmeth774.

(10) Brun, V.; Masselon, C.; Garin, J.; Dupuis, A. Isotope Dilution Strategies for Absolute Quantitative Proteomics. J. Proteomics 2009, $72 \quad$ (5), 740-749. https://doi.org/10.1016/j.jprot.2009.03.007.

(11) Villanueva, J.; Carrascal, M.; Abian, J. Isotope Dilution Mass Spectrometry for Absolute Quantification in Proteomics: Concepts and Strategies. J. Proteomics 2014, 96, 184-199. https://doi.org/10.1016/j.jprot.2013.11.004.

(12) Shuford, C. M.; Walters, J. J.; Holland, P. M.; Sreenivasan, U.; Askari, N.; Ray, K.; Grant, R. P. Absolute Protein Quantification by Mass Spectrometry: Not as Simple as Advertised. Anal. Chem. 2017, $89 \quad$ (14), 7406-7415. https://doi.org/10.1021/acs.analchem.7b00858.

(13) Scott, K. B.; Turko, I. V.; Phinney, K. W. Quantitative Performance of Internal Standard Platforms for Absolute Protein Quantification Using Multiple Reaction MonitoringMass Spectrometry. Anal. Chem. 2015, 87 (8), 4429-4435. https://doi.org/10.1021/acs.analchem.5b00331.

(14) Carroll, K. M.; Simpson, D. M.; Eyers, C. E.; Knight, C. G.; Brownridge, P.; Dunn, W. B.; Winder, C. L.; Lanthaler, K.; Pir, P.; Malys, N.; et al. Absolute Quantification of the 
Glycolytic Pathway in Yeast: Deployment of a Complete QconCAT Approach. Mol. Cell. Proteomics 2011, 10 (12), 1-15. https://doi.org/10.1074/mcp.M111.007633.

(15) Al-Majdoub, Z. M.; Al Feteisi, H.; Achour, B.; Warwood, S.; Neuhoff, S.; RostamiHodjegan, A.; Barber, J. Proteomic Quantification of Human Blood-Brain Barrier SLC and ABC Transporters in Healthy Individuals and Dementia Patients. Mol. Pharm. 2019, 16 (3), 1220-1233. https://doi.org/10.1021/acs.molpharmaceut.8b01189.

(16) Chen, J.; Wang, M.; Turko, I. V. Quantification of Amyloid Precursor Protein Isoforms Using Quantification Concatamer Internal Standard. Anal. Chem. 2013, 85 (1), 303-307. https://doi.org/10.1021/ac3033239.

(17) Pratt, J. M.; Simpson, D. M.; Doherty, M. K.; Rivers, J.; Gaskell, S. J.; Beynon, R. J. Multiplexed Absolute Quantification for Proteomics Using Concatenated Signature Peptides Encoded by QconCAT Genes. Nat. Protoc. 2006, 1 (2), 1029-1043. https://doi.org/10.1038/nprot.2006.129.

(18) Kito, K.; Okada, M.; Ishibashi, Y.; Okada, S.; Ito, T. A Strategy for Absolute Proteome Quantification with Mass Spectrometry by Hierarchical Use of Peptide-Concatenated Standards. $\quad$ Proteomics $2016, \quad 16 \quad$ (10), $1457-1473$. https://doi.org/10.1002/pmic.201500414.

(19) Bennett, R. J.; Simpson, D. M.; Holman, S. W.; Ryan, S.; Brownridge, P.; Eyers, C. E.; Colyer, J.; Beynon, R. J. DOSCATs: Double Standards for Protein Quantification. Sci. Rep. 2017, 7 (February), 1-12. https://doi.org/10.1038/srep45570.

(20) Shuford, C. M.; Sederoff, R. R.; Chiang, V. L.; Muddiman, D. C. Peptide Production and Decay Rates Affect the Quantitative Accuracy of Protein Cleavage Isotope Dilution Mass Spectrometry (PC-IDMS). Mol. Cell. Proteomics 2012, 11 (9), 814-823. https://doi.org/10.1074/mcp.O112.017145.

(21) Kumar, M.; Joseph, S. R.; Augsburg, M.; Bogdanova, A.; Drechsel, D.; Vastenhouw, N. L.; Buchholz, F.; Gentzel, M.; Shevchenko, A. MS Western, a Method of Multiplexed Absolute Protein Quantification Is a Practical Alternative to Western Blotting. Mol. Cell. Proteomics 2018, 17 (2), 384-396. https://doi.org/10.1074/mcp.O117.067082.

(22) Penkov, S.; Raghuraman, B. K.; Erkut, C.; Oertel, J.; Galli, R.; Ackerman, E. J. M.; Vorkel, D.; Verbavatz, J.-M.; Koch, E.; Fahmy, K. A Metabolic Switch Regulates the Transition between Growth and Diapause in C. Elegans. BMC Biol. 2020, 18 (1), 1-20.

(23) Raghuraman, B. K.; Hebbar, S.; Kumar, M.; Moon, H. K.; Henry, I.; Knust, E.; Shevchenko, A. Absolute Quantification of Proteins in the Eye of Drosophila $\begin{array}{lllll}\text { Melanogaster. } & \text { Proteomics } & \text { 2020, } & 20 & \text { (23), }\end{array}$ https://doi.org/10.1002/pmic.201900049.

(24) Borg, J.; Campos, A.; Diema, C.; Omeñaca, N.; De Oliveira, E.; Guinovart, J.; Vilaseca, M. Spectral Counting Assessment of Protein Dynamic Range in Cerebrospinal Fluid Following Depletion with Plasma-Designed Immunoaffinity Columns. Clin. Proteomics 2011, 8 (1). https://doi.org/10.1186/1559-0275-8-6.

(25) Knittelfelder, O.; Traikov, S.; Vvedenskaya, O.; Schuhmann, A.; Segeletz, S.; Shevchenko, A.; Shevchenko, A. Shotgun Lipidomics Combined with Laser Capture Microdissection: A Tool to Analyze Histological Zones in Cryosections of Tissues. Anal. Chem. 2018, 90 (16), 9868-9878. https://doi.org/10.1021/acs.analchem.8b02004.

(26) Barkovits, K.; Tönges, L.; Marcus, K. CSF Sample Preparation for Data-Independent Acquisition. In Methods in Molecular Biology; 2019; Vol. 2044, pp 61-67. https://doi.org/10.1007/978-1-4939-9706-0_4.

(27) MacLean, B.; Tomazela, D. M.; Shulman, N.; Chambers, M.; Finney, G. L.; Frewen, B.; Kern, R.; Tabb, D. L.; Liebler, D. C.; MacCoss, M. J. Skyline: An Open Source Document Editor for Creating and Analyzing Targeted Proteomics Experiments. Bioinformatics 2010, 26 (7), 966-968. https://doi.org/10.1093/bioinformatics/btq054. 
(28) Gessulat, S.; Schmidt, T.; Zolg, D. P.; Samaras, P.; Schnatbaum, K.; Zerweck, J.; Knaute, T.; Rechenberger, J.; Delanghe, B.; Huhmer, A.; et al. Prosit: Proteome-Wide Prediction of Peptide Tandem Mass Spectra by Deep Learning. Nat. Methods 2019, 16 (6), 509518. https://doi.org/10.1038/s41592-019-0426-7.

(29) Simpson, D. M.; Beynon, R. J. QconCATs: Design and Expression of Concatenated Protein Standards for Multiplexed Protein Quantification. Anal. Bioanal. Chem. 2012, 404 (4), 977-989. https://doi.org/10.1007/s00216-012-6230-1.

(30) Scott, K. B.; Turko, I. V.; Phinney, K. W. QconCAT: Internal Standard for Protein Quantification, 1st ed.; Elsevier Inc., 2016; Vol. 566. https://doi.org/10.1016/bs.mie.2015.09.022.

(31) Raghuraman, B. K.; Bogdanova, A.; Moon, H.; Rzagalinski, I.; Geertsma, E. R.; Hersemann, L.; Shevchenko, A. Median-Based Absolute Quantification of Proteins Using Fully Unlabeled Generic Internal Standard (FUGIS). J. Proteome Res. 2021. https://doi.org/10.1021/acs.jproteome.1c00596.

(32) Winter, D.; Seidler, J.; Kugelstadt, D.; Derrer, B.; Kappes, B.; Lehmann, W. D. Minimally Permutated Peptide Analogs as Internal Standards for Relative and Absolute Quantification of Peptides and Proteins. Proteomics 2010, 10 (7), 1510-1514. https://doi.org/10.1002/pmic.200900695.

(33) Remily-Wood, E. R.; Koomen, J. M. Evaluation of Protein Quantification Using Standard Peptides Containing Single Conservative Amino Acid Replacements. J. Mass Spectrom. 2012, 47 (2), 188-194. https://doi.org/10.1002/jms.2053.

(34) Lange, V.; Picotti, P.; Domon, B.; Aebersold, R. Selected Reaction Monitoring for Quantitative Proteomics: A Tutorial. Mol. Syst. Biol. 2008, 4 (222). https://doi.org/10.1038/msb.2008.61.

(35) Dendrou, C. A.; Fugger, L.; Friese, M. A. Immunopathology of Multiple Sclerosis. Nat. Rev. Immunol. 2015, 15 (9), 545-558. https://doi.org/10.1038/nri3871.

(36) Novakova, L.; Zetterberg, H.; Sundström, P.; Axelsson, M.; Khademi, M.; Gunnarsson, M.; Malmeström, C.; Svenningsson, A.; Olsson, T.; Piehl, F.; et al. Monitoring Disease Activity in Multiple Sclerosis Using Serum Neurofilament Light Protein. Neurology 2017, 89 (22), 2230-2237. https://doi.org/10.1212/WNL.0000000000004683.

(37) Canto, E.; Tintore, M.; Villar, L. M.; Costa, C.; Nurtdinov, R.; Alvarez-Cermeno, J. C.; Arrambide, G.; Reverter, F.; Deisenhammer, F.; Hegen, H.; et al. Chitinase 3-like 1: Prognostic Biomarker in Clinically Isolated Syndromes. Brain 2015, 138 (4), 918-931. https://doi.org/10.1093/brain/awv017.

(38) Comabella, M.; Fernández, M.; Martin, R.; Rivera-Vallvé, S.; Borrás, E.; Chiva, C.; Juli, E.; Rovira, A.; Cantó, E.; Alvarez-Cermeño, J. C.; et al. Cerebrospinal Fluid Chitinase 3-like 1 Levels Are Associated with Conversion to Multiple Sclerosis. Brain 2010, 133 (4), 1082-1093. https://doi.org/10.1093/brain/awq035.

(39) Martínez-Morillo, E.; Nielsen, H. M.; Batruch, I.; Drabovich, A. P.; Begcevic, I.; Lopez, M. F.; Minthon, L.; Bu, G.; Mattsson, N.; Portelius, E.; et al. Assessment of Peptide Chemical Modifications on the Development of an Accurate and Precise Multiplex Selected Reaction Monitoring Assay for Apolipoprotein e Isoforms. J. Proteome Res. 2014, 13 (2), 1077-1087. https://doi.org/10.1021/pr401060x.

(40) Minta, K.; Brinkmalm, G.; Janelidze, S.; Sjödin, S.; Portelius, E.; Stomrud, E.; Zetterberg, H.; Blennow, K.; Hansson, O.; Andreasson, U. Quantification of Total Apolipoprotein $\mathrm{e}$ and Its Isoforms in Cerebrospinal Fluid from Patients with Neurodegenerative Diseases. Alzheimer's Res. Ther. 2020, 12 (1), 1-11. https://doi.org/10.1186/s13195-020-00585-7.

(41) Andersson, A.; Remnestål, J.; Nellgård, B.; Vunk, H.; Kotol, D.; Edfors, F.; Uhlén, M.; Schwenk, J. M.; Ilag, L. L.; Zetterberg, H.; et al. Development of Parallel Reaction 
Monitoring Assays for Cerebrospinal Fluid Proteins Associated with Alzheimer's Disease. Clin. Chim. Acta 2019, 494 (March), 79-93. https://doi.org/10.1016/j.cca.2019.03.243.

(42) Zhu, S.; Wuolikainen, A.; Wu, J.; Öhman, A.; Wingsle, G.; Moritz, T.; Andersen, P. M.; Forsgren, L.; Trupp, M. Targeted Multiple Reaction Monitoring Analysis of CSF Identifies UCHL1 and GPNMB as Candidate Biomarkers for ALS. J. Mol. Neurosci. 2019, 69 (4), 643-657. https://doi.org/10.1007/s12031-019-01411-y.

(43) Stoop, M. P.; Singh, V.; Stingl, C.; Martin, R.; Khademi, M.; Olsson, T.; Hintzen, R. Q.; Luider, T. M. Effects of Natalizumab Treatment on the Cerebrospinal Fluid Proteome of Multiple Sclerosis Patients. J. Proteome Res. 2013, 12 (3), 1101-1107. https://doi.org/10.1021/pr3012107.

(44) Ottervald, J.; Franzén, B.; Nilsson, K.; Andersson, L. I.; Khademi, M.; Eriksson, B.; Kjellström, S.; Marko-Varga, G.; Végvári, Á.; Harris, R. A.; et al. Multiple Sclerosis: Identification and Clinical Evaluation of Novel CSF Biomarkers. J. Proteomics 2010, 73 (6), 1117-1132. https://doi.org/10.1016/j.jprot.2010.01.004.

(45) Miyajima, M.; Nakajima, M.; Motoi, Y.; Moriya, M.; Sugano, H.; Ogino, I.; Nakamura, E.; Tada, N.; Kunichika, M.; Arai, H. Leucine-Rich A2-Glycoprotein Is a Novel Biomarker of Neurodegenerative Disease in Human Cerebrospinal Fluid and Causes Neurodegeneration in Mouse Cerebral Cortex. PLoS One 2013, 8 (9), 1-12. https://doi.org/10.1371/journal.pone.0074453.

(46) Chong, P. F.; Sakai, Y.; Torisu, H.; Tanaka, T.; Furuno, K.; Mizuno, Y.; Ohga, S.; Hara, T.; Kira, R. Leucine-Rich Alpha-2 Glycoprotein in the Cerebrospinal Fluid Is a Potential Inflammatory Biomarker for Meningitis. J. Neurol. Sci. 2018, 392 (May), 51-55. https://doi.org/10.1016/j.jns.2018.07.006.

(47) Kušnierová, P.; Zeman, D.; Hradílek, P.; Zapletalová, O.; Stejskal, D. Determination of Chitinase 3-like 1 in Cerebrospinal Fluid in Multiple Sclerosis and Other Neurological Diseases. PLoS One 2020, 15 (5), 1-14. https://doi.org/10.1371/journal.pone.0233519.

(48) Gil-Perotin, S.; Castillo-Villalba, J.; Cubas-Nuñez, L.; Gasque, R.; Hervas, D.; GomezMateu, J.; Alcala, C.; Perez-Miralles, F.; Gascon, F.; Dominguez, J. A.; et al. Combined Cerebrospinal Fluid Neurofilament Light Chain Protein and Chitinase-3 Like-1 Levels in Defining Disease Course and Prognosis in Multiple Sclerosis. Front. Neurol. 2019, 10 (September), 1-11. https://doi.org/10.3389/fneur.2019.01008.

(49) Batruch, I.; Lim, B.; Soosaipillai, A.; Brinc, D.; Fiala, C.; Diamandis, E. P. Mass Spectrometry-Based Assay for Targeting Fifty-Two Proteins of Brain Origin in Cerebrospinal Fluid. J. Proteome Res. 2020, 19 (8), 3060-3071. https://doi.org/10.1021/acs.jproteome.0c00087.

(50) Wahrle, S. E.; Shah, A. R.; Fagan, A. M.; Smemo, S.; Kauwe, J. S. K.; Grupe, A.; Hinrichs, A.; Mayo, K.; Jiang, H.; Thal, L. J.; et al. Apolipoprotein E Levels in Cerebrospinal Fluid and the Effects of ABCAI Polymorphisms. Mol. Neurodegener. 2007, 2 (1), 1-9. https://doi.org/10.1186/1750-1326-2-7.

(51) Roher, A. E.; Maarouf, C. L.; Sue, L. I.; Hu, Y.; Wilson, J.; Beach, T. G. ProteomicsDerived Cerebrospinal Fluid Markers of Autopsy-Confirmed Alzheimer's Disease. Biomarkers 2009, 14 (7), 493-501. https://doi.org/10.3109/13547500903108423.

(52) Kuiperij, H. B.; Hondius, D. C.; Kersten, I.; Versleijen, A. A. M.; Rozemuller, A. J. M.; Greenberg, S. M.; Schreuder, F. H. B. M.; Klijn, C. J. M.; Verbeek, M. M. Apolipoprotein D: A Potential Biomarker for Cerebral Amyloid Angiopathy. Neuropathol. Appl. Neurobiol. 2020, $46 \quad$ (5), 431-440. https://doi.org/10.1111/nan.12595.

(53) Reindl, M.; Knipping, G.; Wicher, I.; Dilitz, E.; Egg, R.; Deisenhammer, F.; Berger, T. Increased Intrathecal Production of Apolipoprotein D in Multiple Sclerosis. $J$. 
bioRxiv preprint doi: https://doi.org/10.1101/2021.12.28.474379; this version posted December 29, 2021. The copyright holder for this preprint (which was not certified by peer review) is the author/funder, who has granted bioRxiv a license to display the preprint in perpetuity. It is made available under aCC-BY-NC-ND 4.0 International license.

Neuroimmunol. 2001, 119 (2), 327-332. https://doi.org/10.1016/S0165-5728(01)003782.

(54) Tumani, H.; Rau, D.; Lehmensiek, V.; Guttmann, I.; Tauscher, G.; Palm, C.; Hirt, V.; Süssmuth, S. D.; Brettschneider, J. Liquorproteomanalyse Bei Klinisch Isoliertem Syndrom Und MS. Nervenarzt 2009, 80 (S1), 30-31. https://doi.org/10.1007/s00115009-2777-2.

(55) Duits, F. H.; Brinkmalm, G.; Teunissen, C. E.; Brinkmalm, A.; Scheltens, P.; Van Der Flier, W. M.; Zetterberg, H.; Blennow, K. Synaptic Proteins in CSF as Potential Novel Biomarkers for Prognosis in Prodromal Alzheimer's Disease. Alzheimer's Res. Ther. 2018, 10 (1), 1-9. https://doi.org/10.1186/s13195-017-0335-x.

(56) Kroksveen, A. C.; Jaffe, J. D.; Aasebø, E.; Barsnes, H.; Bjørlykke, Y.; Franciotta, D.; Keshishian, H.; Myhr, K. M.; Opsahl, J. A.; van Pesch, V.; et al. Quantitative Proteomics Suggests Decrease in the Secretogranin-1 Cerebrospinal Fluid Levels during the Disease Course of Multiple Sclerosis. Proteomics 2015, 15 (19), 3361-3369. https://doi.org/10.1002/pmic.201400142.

(57) Bowden, J. A.; Heckert, A.; Ulmer, C. Z.; Jones, C. M.; Koelmel, J. P.; Abdullah, L.; Ahonen, L.; Alnouti, Y.; Armando, A. M.; Asara, J. M.; et al. Harmonizing Lipidomics: NIST Interlaboratory Comparison Exercise for Lipidomics Using SRM 1950Metabolites in Frozen Human Plasma. J. Lipid Res. 2017, 58 (12), 2275-2288. https://doi.org/10.1194/jlr.M079012. 

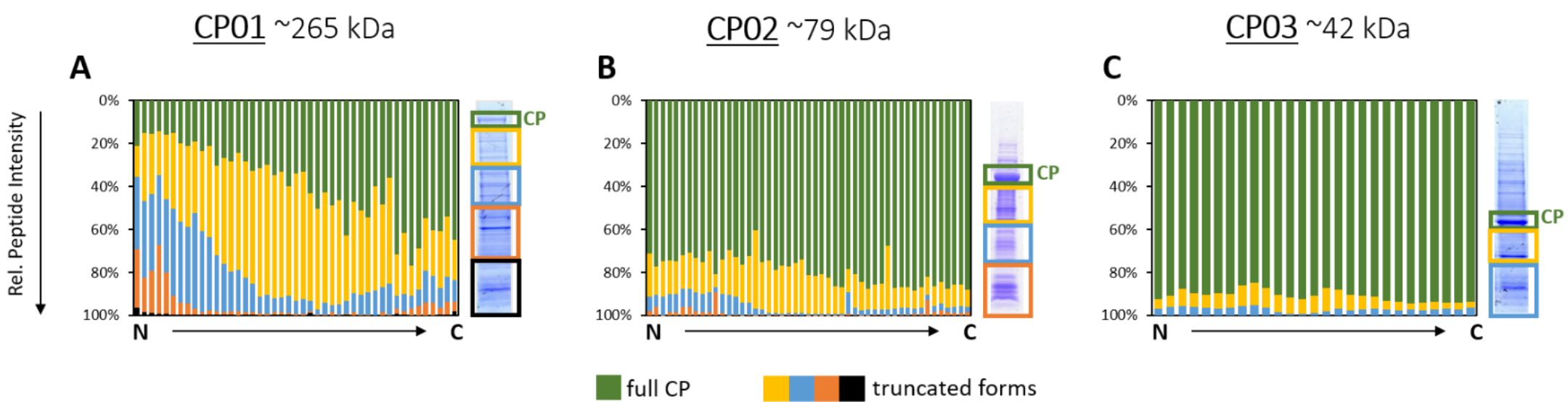

\section{D}

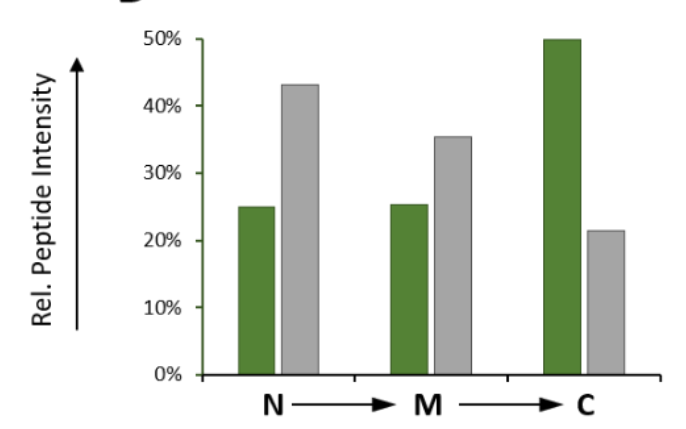

$\mathbf{E}$

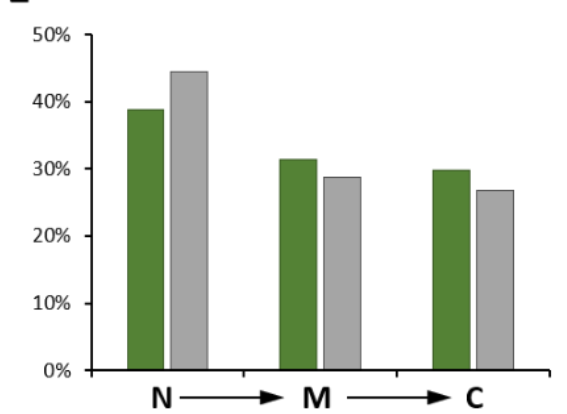

$\mathbf{F}$

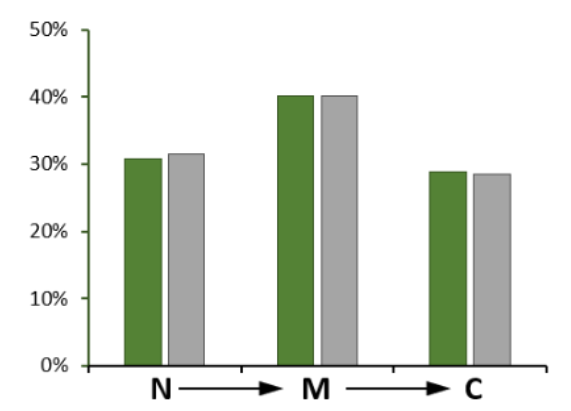

purified CP $\quad$ unpurified CP

Figure 1. Truncation pattern for the chimeric proteins: CP01 $\sim 265 \mathrm{kDa}$ (panels: A, D), CP02 $79 \mathrm{kDa}$ (panels: B, E), CP03 42 kDa (panels: C, $\mathbf{F})$. The upper panels $(\mathbf{A}, \mathbf{B}, \mathbf{C})$ present relative abundance of peptides in SDS-PAGE slabs (y-axis) versus peptides position in $\mathrm{CP}$ sequence $(\mathrm{x}-$ axis); color-coding is exemplified at the right-hand side panel. Lower panels (D, E, F) present relative abundance of peptides from the purified CP (only CP band) versus the non-purified CP (sum of all bands) for selected Q-peptides located at the N-and C-termini as well as for the middle of the CP sequence ("M"). 
Table 1. Comparison of protein quantitation by FastCAT and MS Western.

\begin{tabular}{cccc}
\hline \multirow{2}{*}{ Protein } & \multicolumn{2}{c}{$\begin{array}{c}\text { Calculated amount } \\
\text { [fmol/column }\end{array}$} & $\begin{array}{c}\text { Quantification error } \\
\%\end{array}$ \\
\cline { 2 - 3 } & MS Western & FastCAT & \\
\hline GP & 197.5 & 189.9 & $3.8 \%$ \\
UBI & nq & 231.2 & $\mathrm{nq}$ \\
ADH & 205.9 & 183.0 & $11.1 \%$ \\
ENO & 222.9 & 208.9 & $6.3 \%$ \\
\hline
\end{tabular}

${ }^{1}$ Proteins were quantified by averaging the amounts calculated using 3 to 5 Q-peptides. UBI was not detected/quantified (nq) by MS Western. 
A

CP04 (R-peptides at $N$, “ $M$ " and $C$ )

Target proteins amounts [fmol/column] calculated with CPO4 quantified by different R-peptides

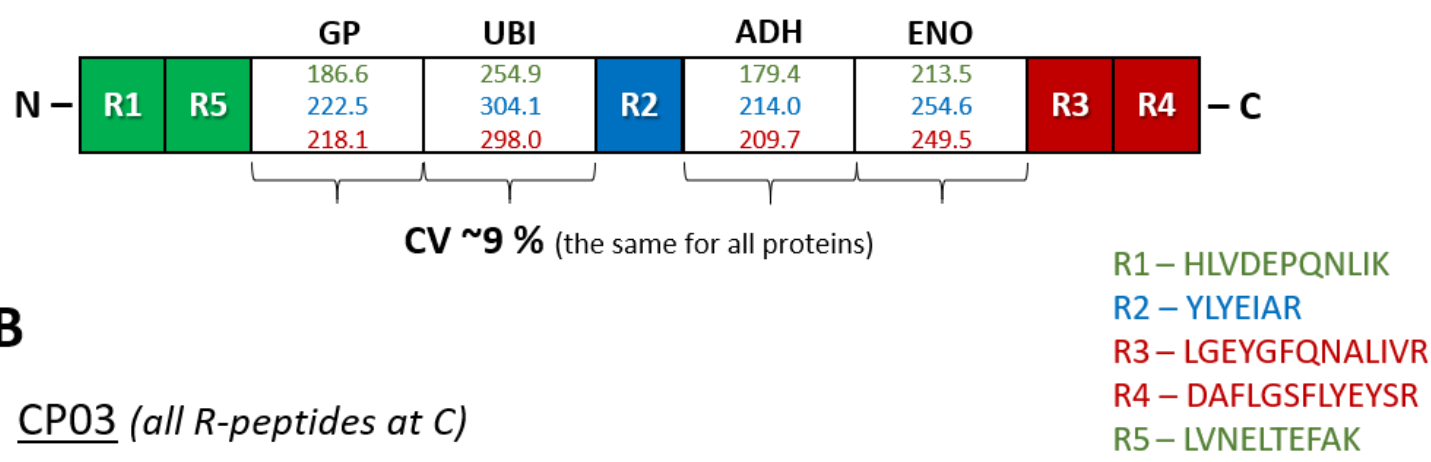

Target proteins amounts [fmol/column] calculated with CP03 quantified by different R-peptides

\begin{tabular}{|c|c|c|c|c|c|c|c|c|c|c|}
\hline & GP & UBI & $\mathrm{ADH}$ & ENO & \multirow{4}{*}{ R1 } & \multirow{4}{*}{$\mathbf{R} 2$} & \multirow{4}{*}{ R3 } & \multirow{4}{*}{ R4 } & \multirow{4}{*}{ R5 } & \\
\hline & 180.0 & 217.1 & 168.0 & 196.8 & & & & & & \\
\hline & 204.9 & 227.0 & 175.7 & 205.9 & & & & & & $-C$ \\
\hline $\mathbf{N}-$ & 185.0 & 247.1 & 191.3 & 224.1 & & & & & & \\
\hline
\end{tabular}

Figure 2. Impact of the position of R-peptides within $\mathrm{CP}$ sequence on proteins quantification. Comparison of the target proteins quantification by using CP04 and N-vs. "M" vs. C-terminus R-peptides as well as by using CP03 and the same groups of peptides but all positioned at Cterminus. 


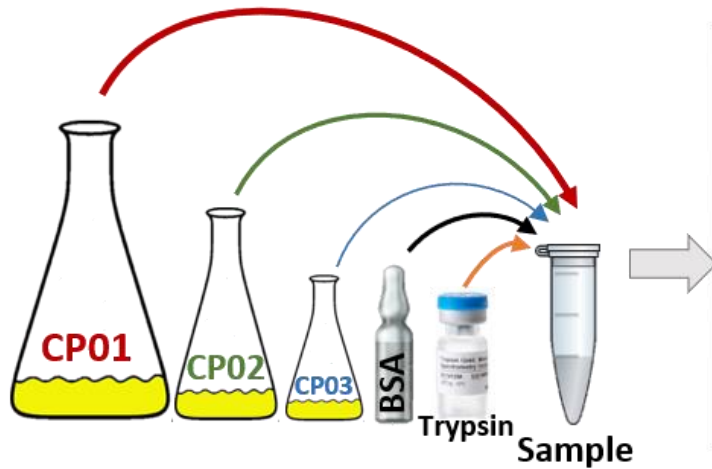

In-solution co-digestion of sample (e.g. CSF), non-purified CPs (multiple at different amounts) and BSA

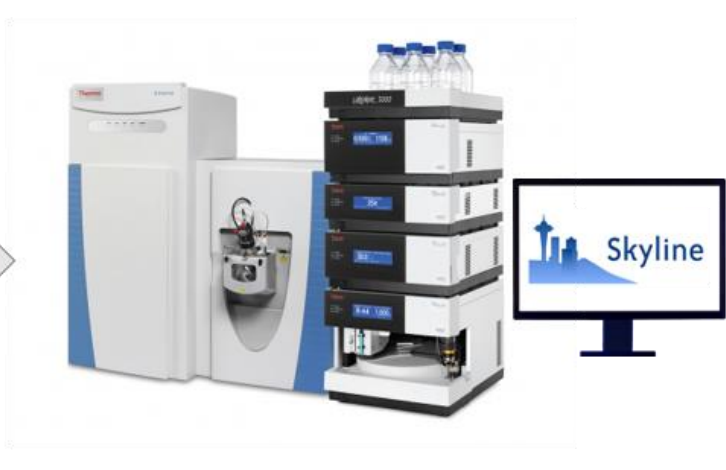

LC-MS/MS targeted proteomics (e.g. PRM) data acquisition and processing

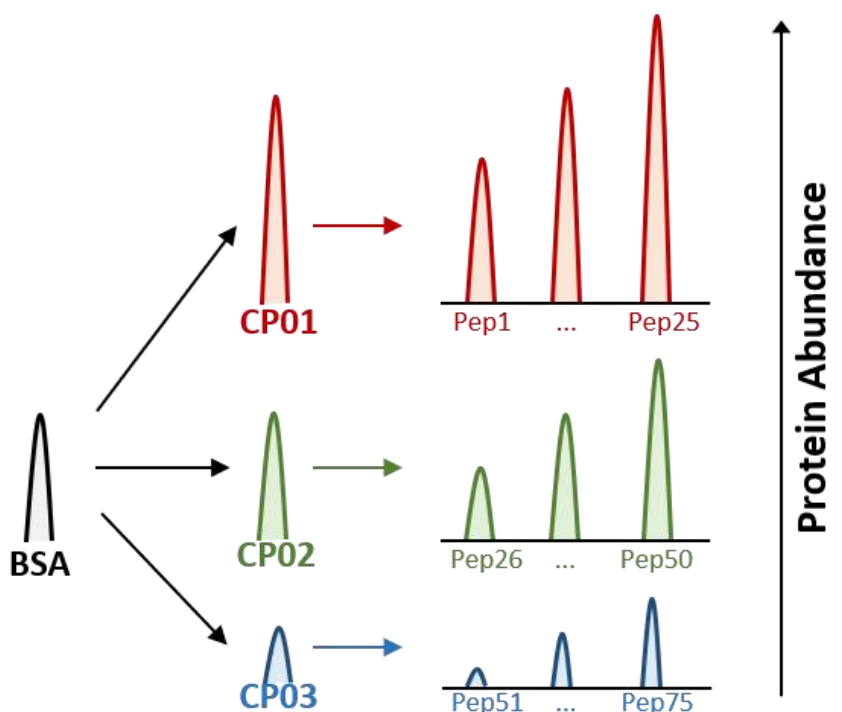

$1^{\text {st }}$ - in-situ quantification of multiple CPs by BSA $2^{\text {nd }}$ - quantification of target proteins by multiple CPs at amounts adjusted to protein abundance

Figure 3. FastCAT workflow using multiple non-purified CP standards for absolute parallel quantification. $1^{\text {st }}$ step: quantification of CPs by their reference peptides and spiked-in BSA; $2^{\text {nd }}$ step: quantification of the target proteins by quantotypic peptides from CPs. Both $1^{\text {st }}$ and $2^{\text {nd }}$ steps are performed together during the same LC-MS/MS run. 


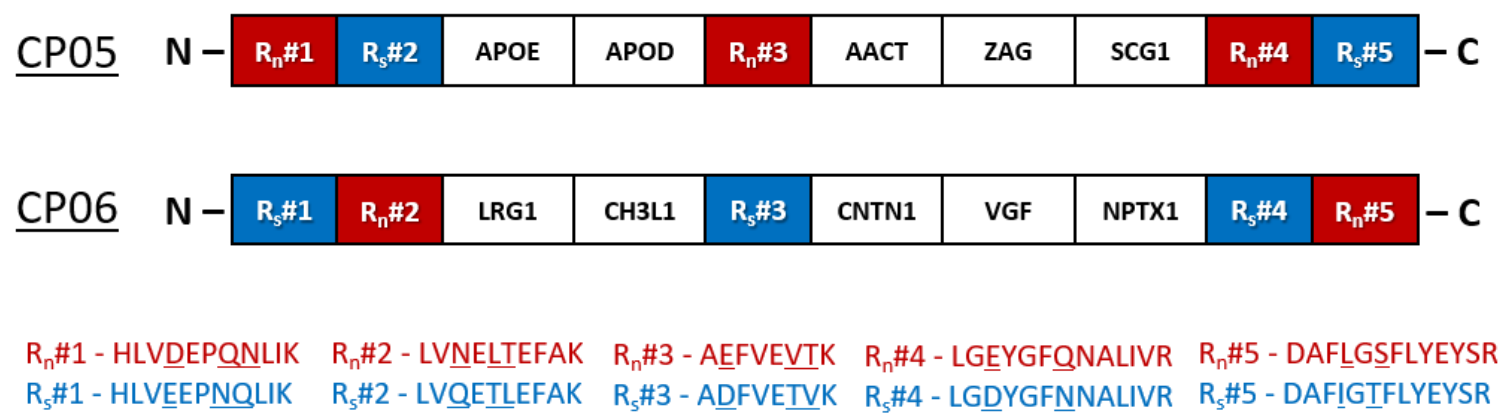

Figure 4. Scheme of CP05 and CP06 constructs comprised of the native $\left(\mathrm{R}_{\mathrm{n}} \# 1-\mathrm{R}_{\mathrm{n}} \# 5\right)$ and scrambled $\left(\mathrm{R}_{\mathrm{s}} \# 1-\mathrm{R}_{\mathrm{s}} \# 5\right)$ forms of 5 BSA peptides (shown as one block/peptide) as well as the multiple Q-peptides from 10 target proteins (shown as one block/protein). 

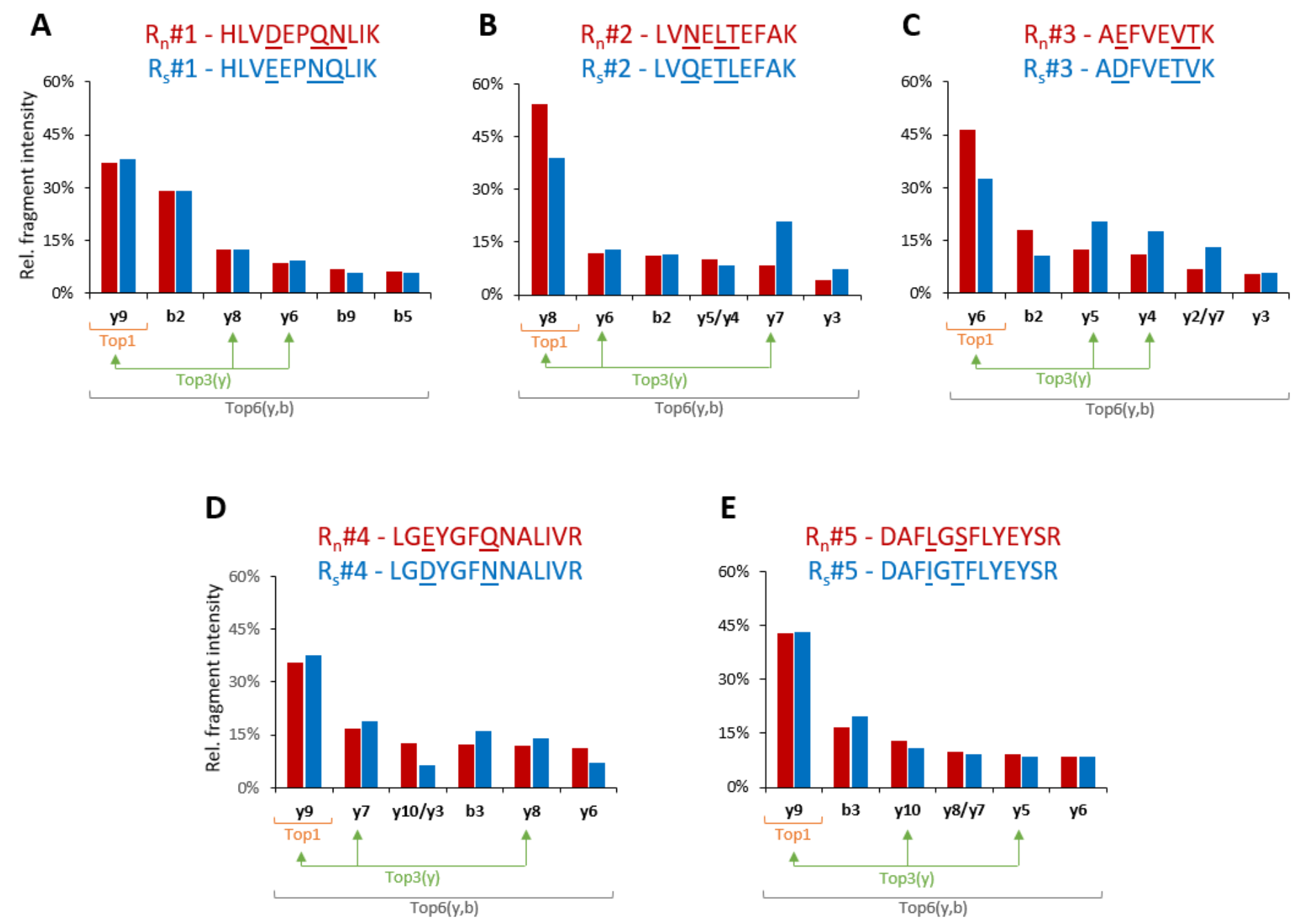

Figure 5. Relative abundance of the most intense six fragment ions (within y- and b-ions) from the native (BSA/light - red bars) and scrambled (CP/heavy - blue bars) R-peptides. In four of five pairs one fragment ion within the top 6 did not match between the native and scrambled forms and in this situation the non-matching fragments were presented together for better visibility of the fragmentation differences. 


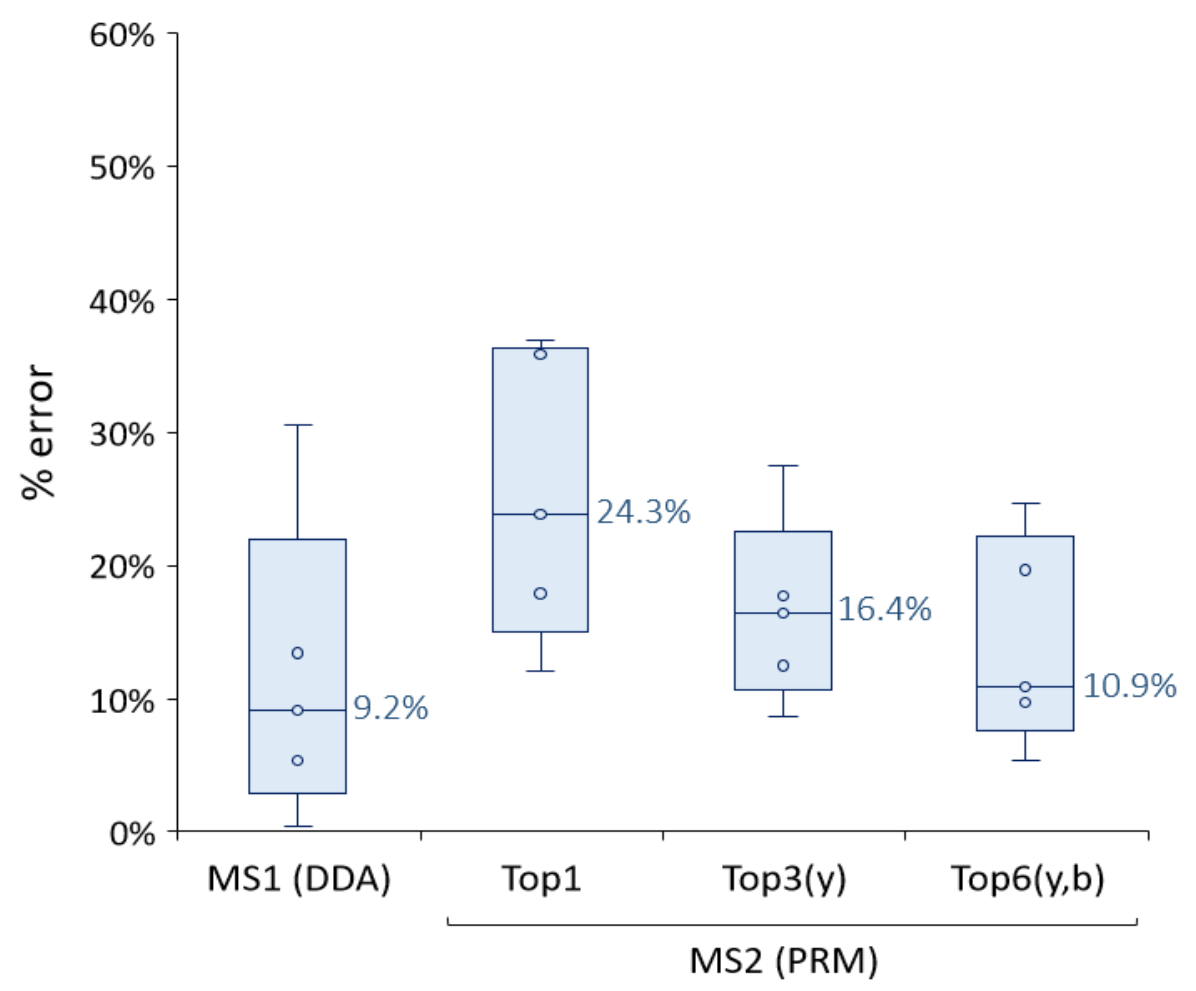

Figure 6. Relative error in the quantification of CPs by using $\mathrm{R}_{\mathrm{s}}$-peptides and either MS1 or MS2 (summed) intensities of different fragment ions. Top1 (the top fragment ion); Top3(y) (sum of the top three $y$-ions, matching between $R_{n}$ and $R_{s}$ ); Top6(y,b) (sum of the top six fragments within $\mathrm{y}$ - and b-ions). Each box contains information from $5 \mathrm{R}_{\mathrm{s}}$-peptides (detailed information is provided in Table S2 in SI), while the median values are given next to the boxes. Each box plot displays the median (line), the 25th and 75th percentiles (box), and the 5th and 95th percentiles (whiskers). 


\begin{tabular}{|c|c|c|c|c|c|}
\hline Protein & $\begin{array}{c}\text { UniProt } \\
\text { accession }\end{array}$ & $\begin{array}{l}\text { Q-peptides } \\
\text { sequences }\end{array}$ & $\begin{array}{l}\text { Intra-protein } \\
\text { peptide concordance } \\
\text { (median CV [\%]) }\end{array}$ & $\begin{array}{c}\text { Concentration range } \\
\text { (median) } \\
{[\mathrm{ng} / \mathrm{mL}]}\end{array}$ & $\begin{array}{l}\text { Lit. reported concentration range } \\
\text { (method and ref.) } \\
{[\mathrm{ng} / \mathrm{mL}]}\end{array}$ \\
\hline$\overline{\mathrm{APOE}}$ & P02649 & $\begin{array}{c}\text { SELEEQLTPVAEETR } \\
\text { LGPLVEQGR } \\
\text { QWAGLVEK } \\
\text { LAVYQAGAR }\end{array}$ & 7.5 & $\begin{array}{c}922.1-2075.6 \\
(1807.8)\end{array}$ & $\begin{array}{c}900-3000(\mathrm{SRM})^{39} \\
2964-3112(\mathrm{PRM})^{40} \\
7000-12000(\text { ELISA) } \\
4000-13000 \text { (ELISA) }^{50}\end{array}$ \\
\hline APOD & P05090 & $\begin{array}{c}\text { NILTSNNIDVK } \\
\text { NPNLPPETVDSLK } \\
\text { VLNQELR } \\
\text { WYEIEK }\end{array}$ & 5.7 & $\begin{array}{l}1060.4-1327.3 \\
\quad(1256.6)\end{array}$ & $3000-12000$ (ELISA) $^{52}$ \\
\hline$\overline{\mathrm{AACT}}$ & $\mathrm{P} 01011$ & $\begin{array}{c}\text { ITLLSALVETR } \\
\text { NLAVSQVVHK } \\
\text { AVLDVFEEGTEASAATAVK } \\
\text { ADLSGITGAR } \\
\end{array}$ & 10.1 & $\begin{array}{l}540.9-1127.3 \\
(724.0)\end{array}$ & $\begin{array}{c}126-2954 \text { (PRM) }^{41} \\
1400-3900 \text { (ELISA) }^{44}\end{array}$ \\
\hline$\overline{Z A G}$ & P25311 & $\begin{array}{l}\text { EIPAWVPFDPAAQITK } \\
\text { WEAEPVYVQR }\end{array}$ & 9.0 & $\begin{array}{l}85.2-113.2 \\
(96.3)\end{array}$ & $\mathrm{n} / \mathrm{a}$ \\
\hline SCG1 & P05060 & $\begin{array}{c}\text { NYPSLELDK } \\
\text { NYLNYGEEGAPGK } \\
\text { WQQQGDLQDTK }\end{array}$ & 12.4 & $\begin{array}{c}388.6-942.3 \\
(850.1)\end{array}$ & $300-900(\mathrm{SRM})^{42}$ \\
\hline$\overline{\text { LRG1 }}$ & P02750 & $\begin{array}{l}\text { VAAGAFQGLR } \\
\text { GQTLLAVAK }\end{array}$ & 14.0 & $\begin{array}{l}27.1-114.3 \\
(68.0)\end{array}$ & $\begin{array}{l}25-350 \text { (ELISA) }^{45} \\
90-800 \text { (ELISA) }^{46}\end{array}$ \\
\hline$\overline{\mathrm{CH} 3 \mathrm{~L} 1}$ & P36222 & $\begin{array}{c}\text { FPLTNAIK } \\
\text { ILGQQVPYATK } \\
\text { VTIDSSYDIAK } \\
\text { GNQWVGYDDQESVK }\end{array}$ & 5.8 & $\begin{array}{l}25.7-53.8 \\
(35.2)\end{array}$ & $\begin{array}{c}35-254(\text { SRM })^{43} \\
70-160(\text { ELISA) } \\
29-182(\text { ELISA) } \\
\text { 37 } \\
30-350(\text { ELISA) })^{48}\end{array}$ \\
\hline CNTN1 & Q12860 & $\begin{array}{l}\text { FIPLIPIPER } \\
\text { ASPFPVYK }\end{array}$ & 12.4 & $\begin{array}{c}148.3-268.6 \\
(238.9)\end{array}$ & $20-300\left(\right.$ ELISA) ${ }^{44}$ \\
\hline VGF & O15240 & $\begin{array}{c}\text { NSEPQDEGELFQGVDPR } \\
\text { THLGEALAPLSK }\end{array}$ & 30.9 & $\begin{array}{c}60.6-175.9 \\
(111.0)\end{array}$ & $\mathrm{n} / \mathrm{a}$ \\
\hline$\overline{\text { NPTX1 }}$ & Q15818 & $\begin{array}{c}\text { FQLTFPLR } \\
\text { TPAAETLSQLGQTLQSLK }\end{array}$ & 5.6 & $\begin{array}{c}37.2-86.0 \\
(72.0) \\
\end{array}$ & $\mathrm{n} / \mathrm{a}$ \\
\hline
\end{tabular}

Table 2. Proteins concentrations (ranges and median) obtained from eleven CSF samples from patients with multiple sclerosis, together with UniProt accessions, Q-peptides used for quantification, intra-protein concordance (median CV from all samples) as well as the CSF concentrations reported for those proteins in literature by using both mass spectrometric (either PRM or SRM) and ELISA methods. Proteins: APOE (apolipoprotein E), APOD (apolipoprotein D), AACT (Alpha-1-antichymotrypsin), ZAG (Zinc-alpha-2-glycoprotein), SCG1 (Secretogranin1/Chromogranin B), LRG1 (Leucine-rich alpha-2-glycoprotein 1), CH3L1 (Chitinase-3-like protein), CNTN1 (Contactin-1), VGF (Neurosecretory protein VGF), NPTX1 (Neuronal pentraxin-1). 


\section{Supporting Information}

\section{FastCAT accelerates absolute quantification of proteins by using multiple short non-purified chimeric standards}

Ignacy Rzagalinski ${ }^{1}$, Aliona Bogdanova ${ }^{1}$, Bharath Kumar Raghuraman ${ }^{1}$, Eric R. Geertsma ${ }^{1}$, Lena Hersemann $^{1}$, Tjalf Ziemssen ${ }^{2}$, Andrej Shevchenko ${ }^{1 *}$

${ }^{1}$ Max Planck Institute of Molecular Cell Biology and Genetics, 01307 Dresden, Germany

${ }^{2}$ Center of Clinical Neuroscience, Department of Neurology, University Hospital Carl Gustav Carus, Technical University of Dresden, 01307 Dresden, Germany

Table of Content

Figure S1 Scheme of chimeric protein (CP)

Figure S2 E. coli background in non-purified CP

Figure S3 Amino acid sequences of CP05/CP06

Figure S4 Truncation patterns for CP05/CP06

Figure S5 Tandem mass spectra for $R_{n} / R_{s}$-peptides

Figure S6 Relative $\mathrm{R}_{\mathrm{n}} / \mathrm{R}_{\mathrm{s}}$-peptides abundances for CP05/CP06 vs. BSA

Table S1 E. coli background proteins used for comparison in Figure S2

Table S2 Error in quantification of CPs by $\mathrm{R}_{\mathrm{s}}$-peptides

Table S3 Protein concentrations in CSF from individual patients

Table S4 Amino acid sequences for all used CPs 
bioRxiv preprint doi: https://doi org/10.1101/2021.12 28.474379. this version posted December 29, 2021. The copyright holder for this preprint (which was not certified by peer review) is the author/funder, who has granted bioRxiv a license to display the preprint in perpetuity. It is made available under aCC-BY-NC-ND 4.0 International license.

Chimeric protein (CP) standard

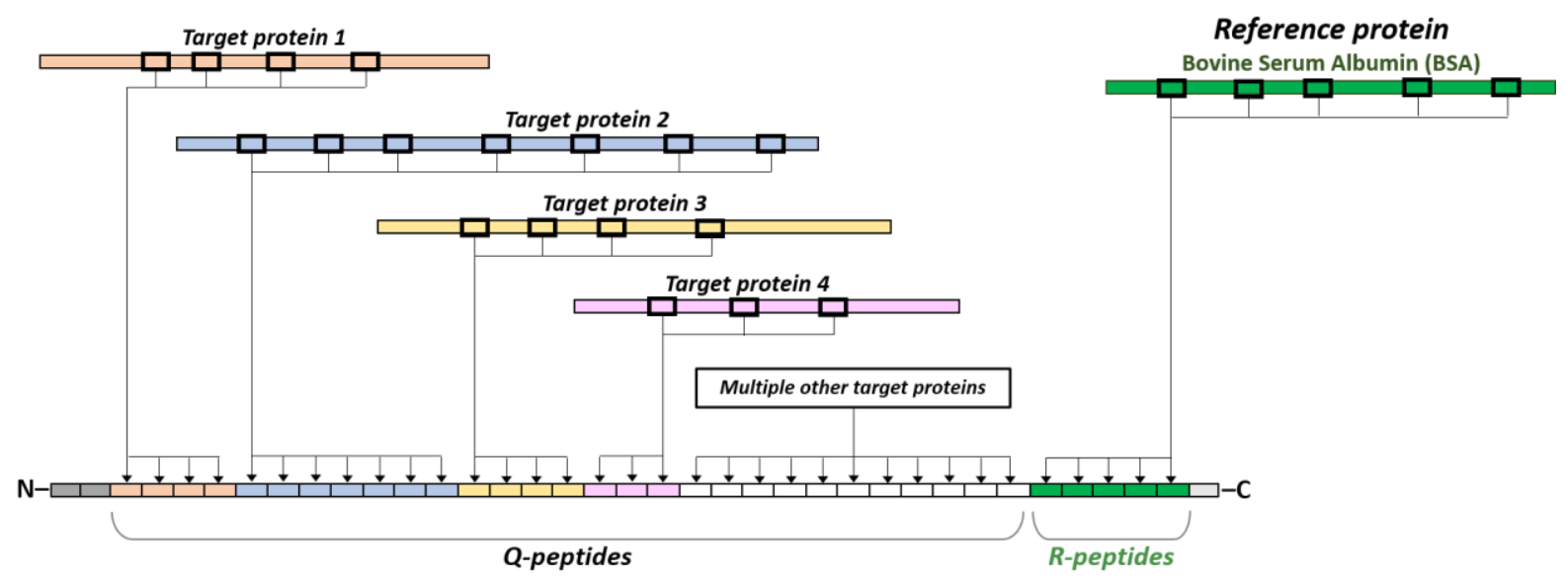

Figure S1. Scheme of chimeric protein (CP) standard. 


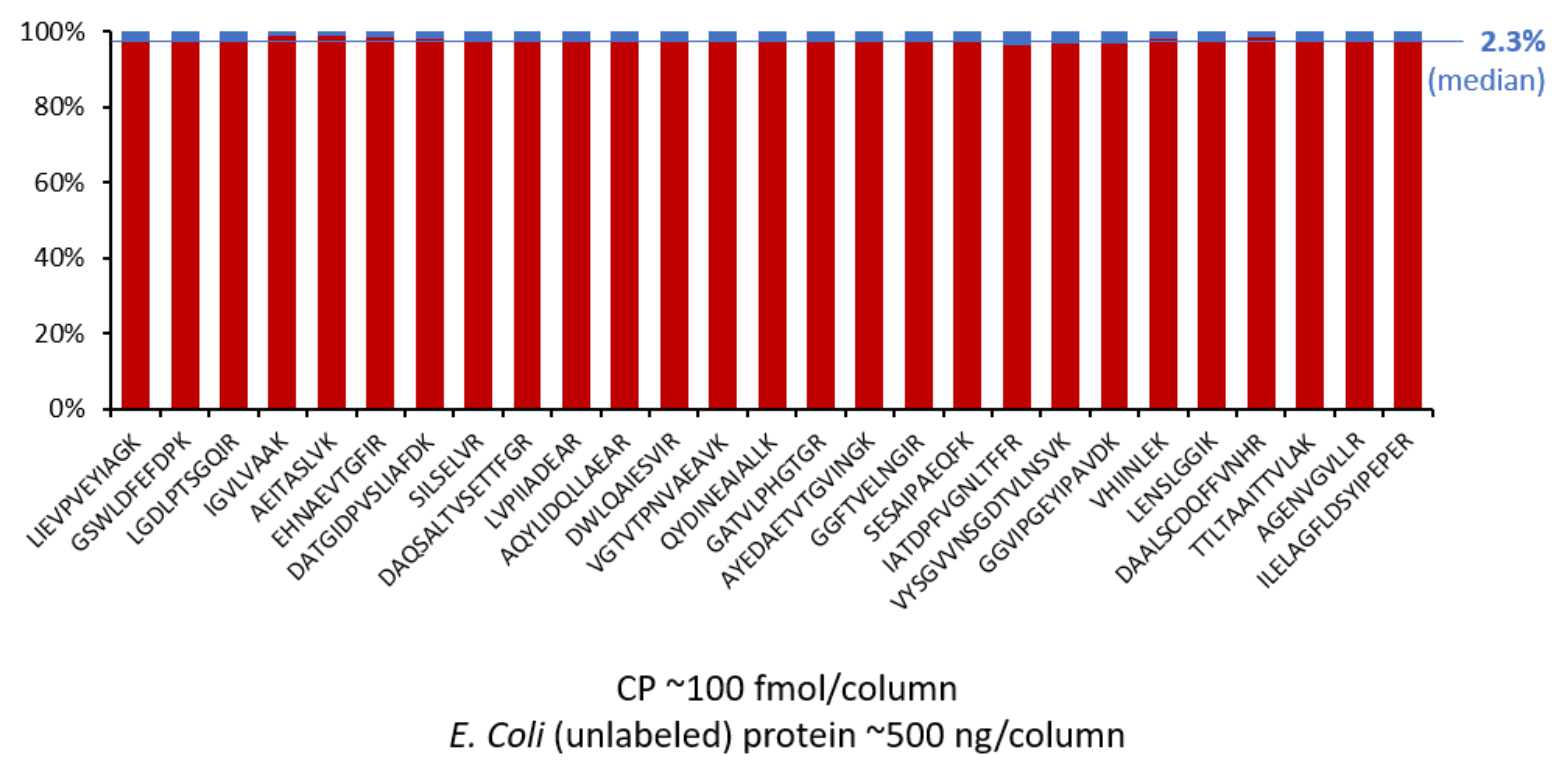

Figure S2. Contribution of an extra background from the expression host (E. coli) introduced with the non-purified CP standard (labeled, blue bars) in comparison with original E. coli sample (unlabeled/endogenous, red bars), shown for the typical working conditions with CP at approximately $100 \mathrm{fmol}$ on column and total protein load on column ca. $500 \mathrm{ng}$. The contribution of the extra background (labeled) is just $\sim 2 \%$ of the total pool. Importantly, nine highly abundant E. coli proteins (mainly ribosomal and elongation factor proteins) were compared, which were represented by at least three peptides yielding consistent $\mathrm{L} / \mathrm{H}$ ratios (see Table S1). Of note, only the peptides observed with one predominant charge state, free of missed cleavages as well as free of cysteine and methionine residues were selected. Moreover, CP labeling efficiency was above $99 \%$ so virtually all unlabeled peptides originated from the original E. coli sample. 


\section{A \\ CP05}

MGSAWSHPQFEKGGGSGGGSGGSAWSHPQFEKLEVLFQGPAAAKVFADYEEYVKDFYELEPHKV AAAFPGDVDRGLAGVENVTELKHLVDEPQNLIKLVQETLEFAKSELEEQLTPVAEETRLGPLVEQGR AATVGSLAGQPLQERQWAGLVEKLAVYQAGARNILTSNNIDVKIPTTFENGRNPNLPPETVDSLKV LNQELRWYEIEKAEFVEVTKITLLSALVETRNLAVSQVVHKAVLDVFEEGTEASAATAVKADLSGITG ARHVEDVPAFQALGSLNDLQFFRYSLTYIYTGLSKEIPAWVPFDPAAQITKQKWEAEPVYVQRNYPS LELDKNYLNYGEEGAPGKGEAGAPGEEDIQGPTKWQQQGDLQDTKLGEYGFQNALIVRDAFIGTF LYEYSRGSGHHHHHH

Apolipoprotein E (APOE) - Apolipoprotein D (APOD) - Alpha-1-antichymotrypsin (AACT) - Zinc-alpha-2glycoprotein (ZAG) - Secretogranin-1 (SCG1) BSA (R-)peptides: native and scrambled

B CP06

MGSAWSHPQFEKGGGSGGGSGGSAWSHPQFEKLEVLFQGPAAAKVFADYEEYVKDFYELEPHKV AAAFPGDVDRGLAGVENVTELKHLVEEPNQLIKLVNELTEFAKVAAGAFQGLRGQTLLAVAKTLDLG ENQLETLPPDLLRENQLEVLEVSWLHGLKFPLTNAIKILGQQVPYATKTLLSVGGWNFGSQRVTIDS SYDIAKGNQWVGYDDQESVKADFVETVKFIPLIPIPERASPFPVYKTDGAAPNVAPSDVGGGGGR VQVTSQEYSARNSEPQDEGELFQGVDPRTHLGEALAPLSKLADLASDLLLQYLLQGGARVGEEDEE AAEAEAEAEEAERFQLTFPLRTPAAETLSQLGQTLQSLKALSGNVIAWAESHIEIYGGATKLGDYG FN NALIVRDAFLGSFLYEYSRGSGHHHHHH

Leucine-rich alpha-2-glycoprotein (A2GL) - Chitinase-3-like protein (CH3L1) - Contactin-1 (CNTN1) Neurosecretory protein VGF (VGF) - Neuronal pentraxin-1 (NPTX1)

BSA (R-)peptides: native and scrambled

Figure S3. Amino acid sequences of the CP05 and CP06 constructs used for quantification of 10 neurological protein markers in CSF samples. 

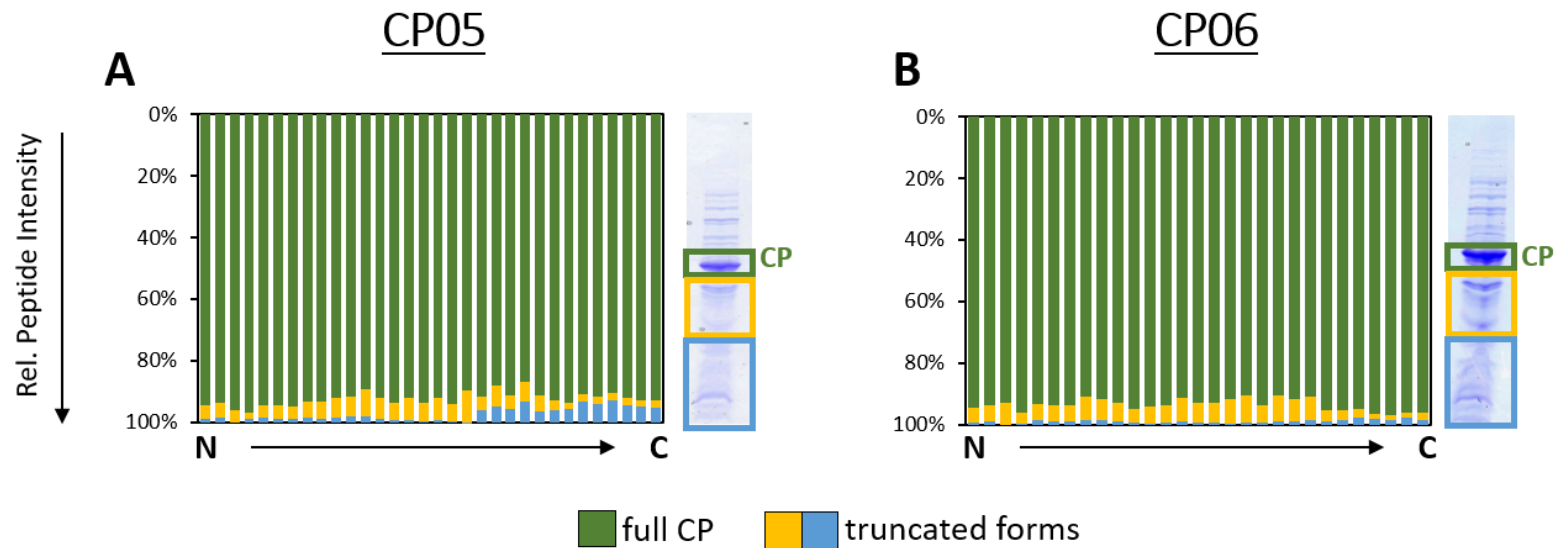

C

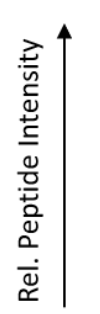

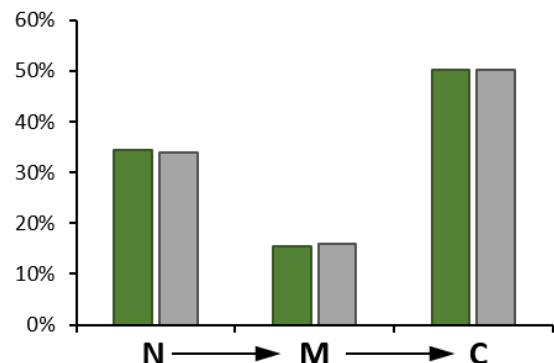

purified CP
D

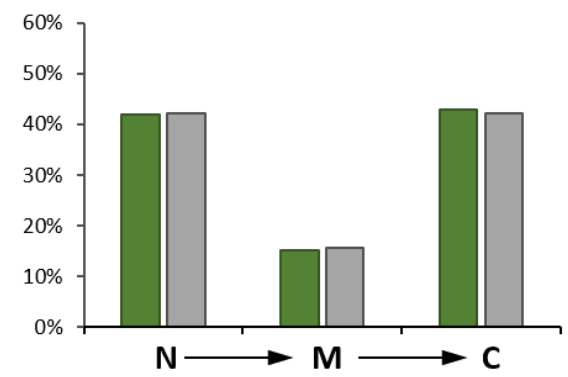

unpurified $\mathrm{CP}$

Figure S4. Truncation patterns for CP05 (A and C) and CP06 (B and D) standards. 
bioRxiv preprint doi: https://doi.org/10.1101/2021.12.28.474379; this version posted December 29, 2021. The copyright holder for this preprint (which was not certified by peer review) is the author/funder, who has granted bioRxiv a license to display the preprint in perpetuity. It is made available under aCC-BY-NC-ND 4.0 International license.

A

HLVDEPQNLIK
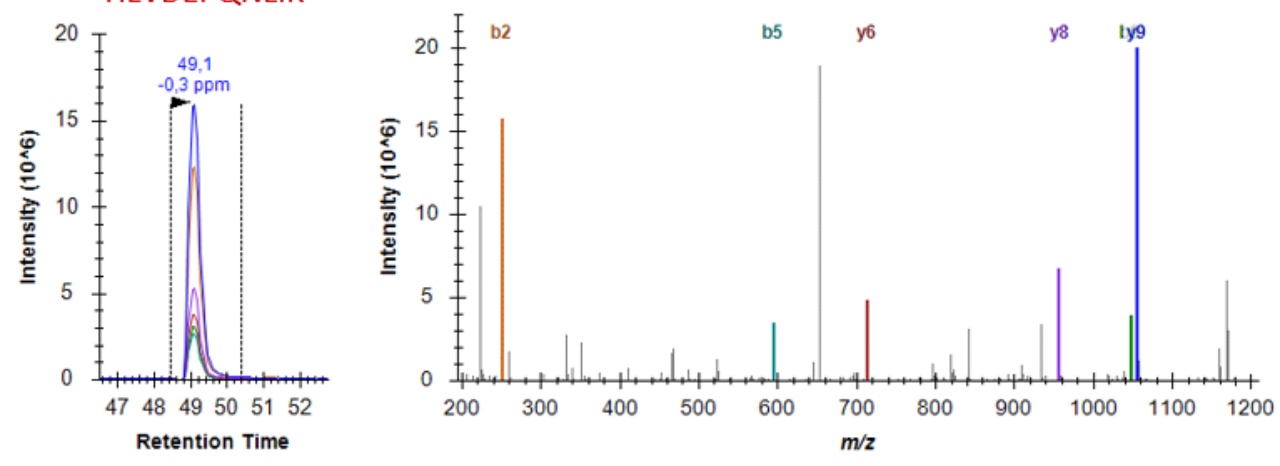

HLVEEPNQLIK
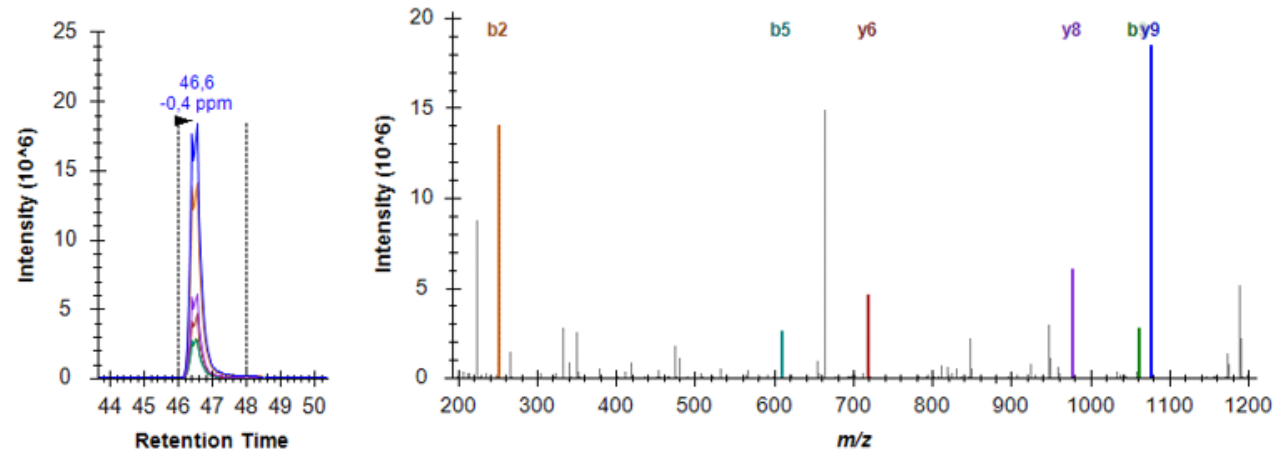

B
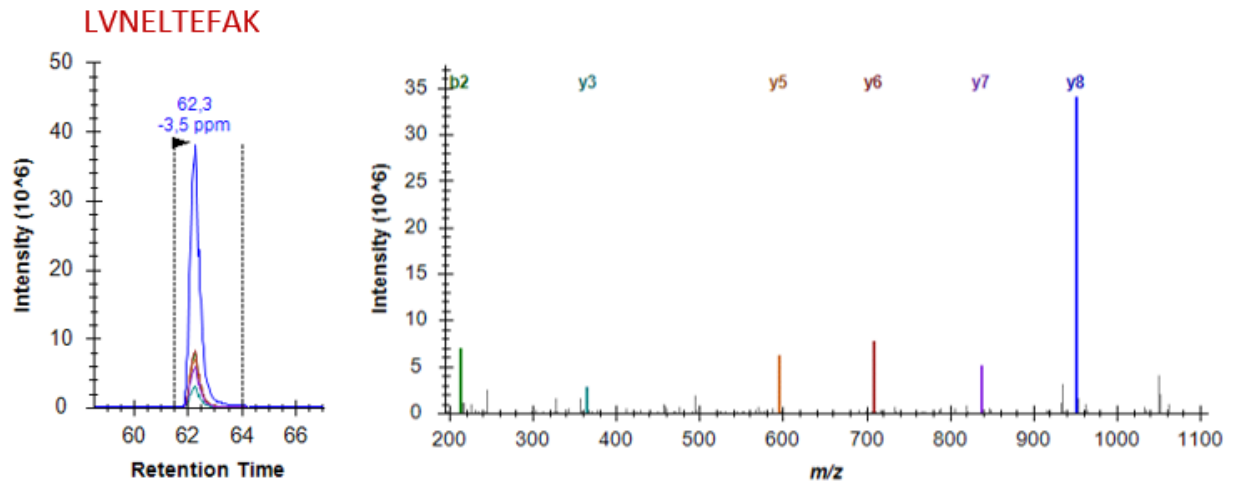

LVQEETLEFAK
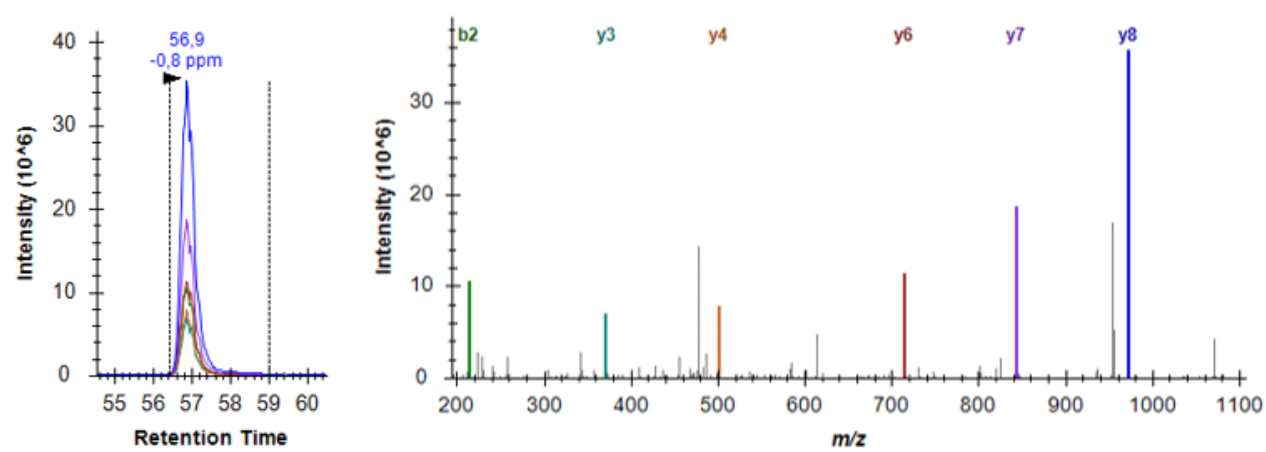
bioRxiv preprint doi: https://doi. org/10.1101/2021.12.28.474379; this version posted December 29, 2021. The copyright holder for this preprint (which was not certified by peer review) is the author/funder, who has granted bioRxiv a license to display the preprint in perpetuity. It is made available under aCC-BY-NC-ND 4.0 International license.

C
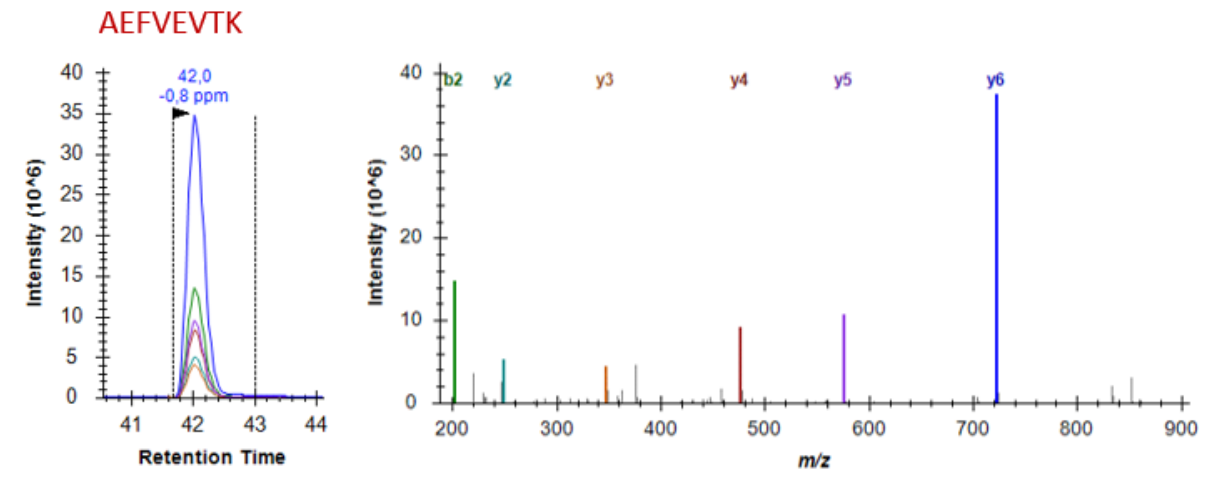

ADFVETVK
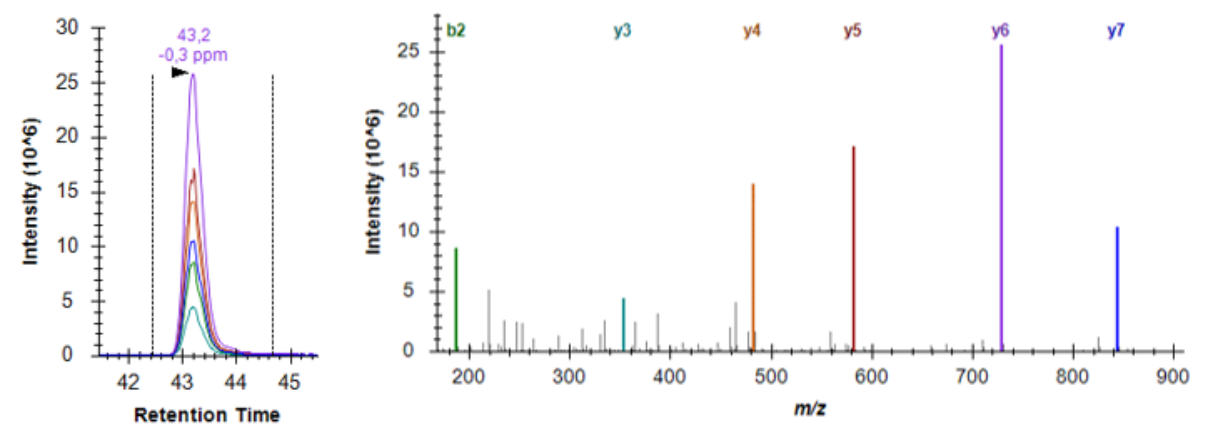

D

LGEYGFQNALIVR
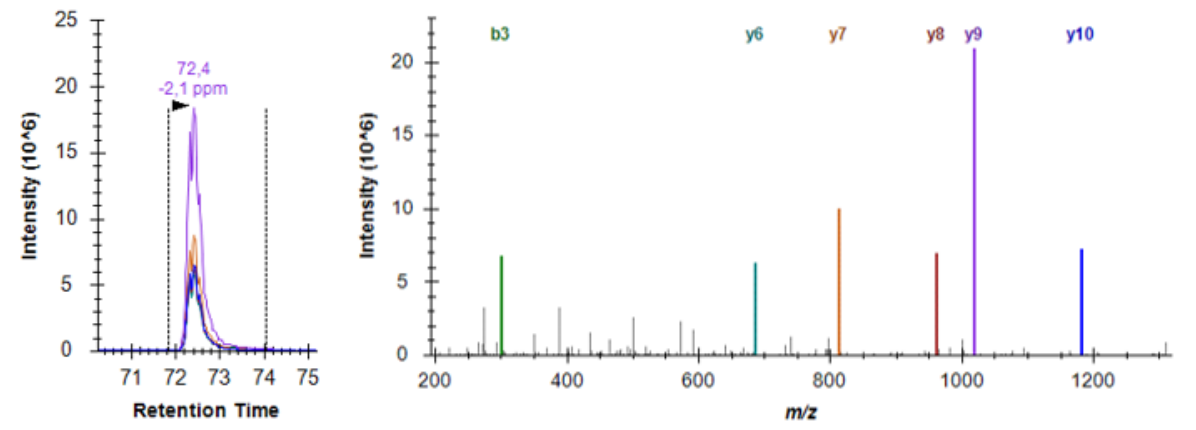

LGDYGF $\underline{N} N A L I V R$
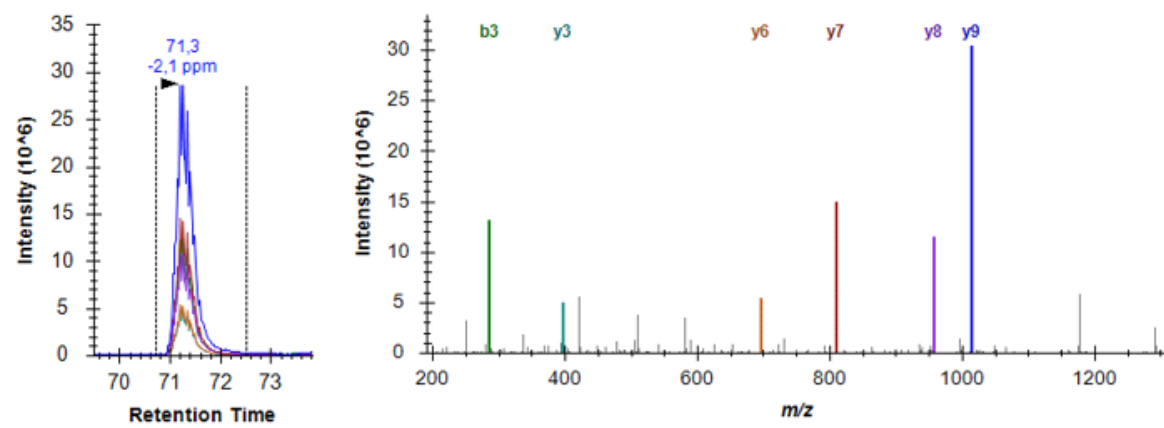


\section{$\mathbf{E}$}

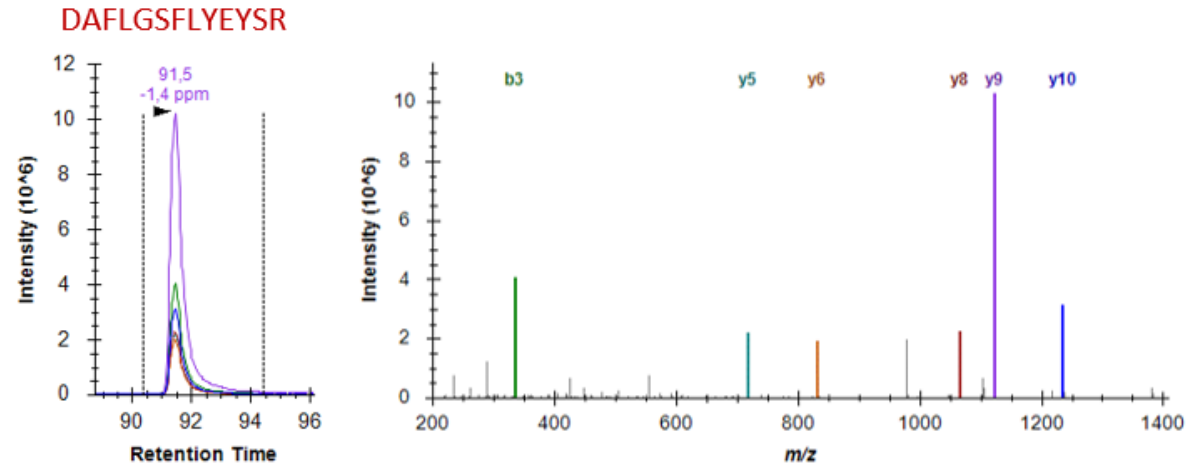

\section{DAFIGIFLYEYSR}
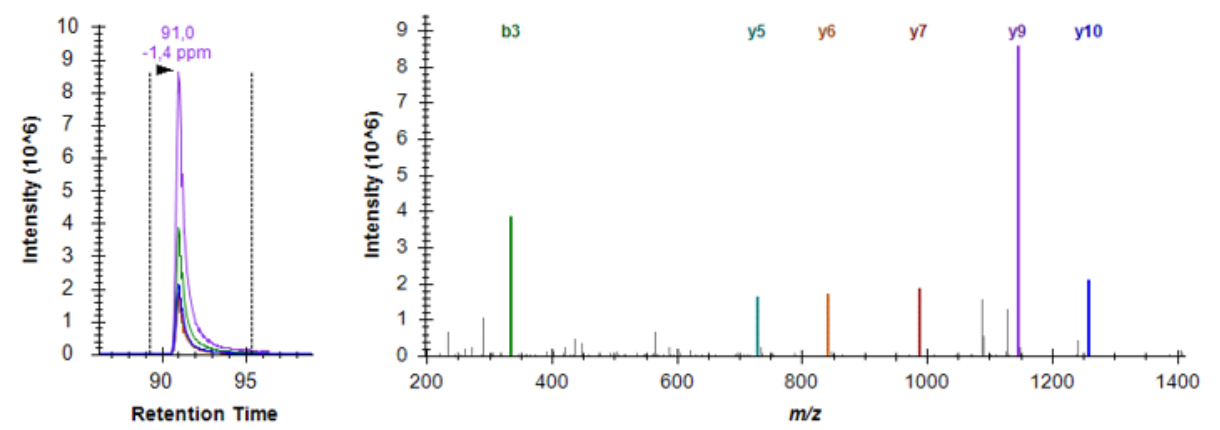

Figure S5. R-peptides tandem mass spectra for their native (BSA, unlabeled) and scrambled forms (CP05/06, labeled) together with their chromatographic peaks: HLVDEPQNLIK (nat) and HLVEEPNQLIK (scr) (A), LVNELTEFAK (nat) and LVQETLEFAK (scr) (B), AEFVEVTK (nat) and ADFVETVK (scr) (C), LGEYGFQNALIVR (nat) and LGDYGGFNNALIVR (scr) (D), DAFLGSFLYEYSR (nat) and DAFIGTFLYEYSR (scr) (E). 
A

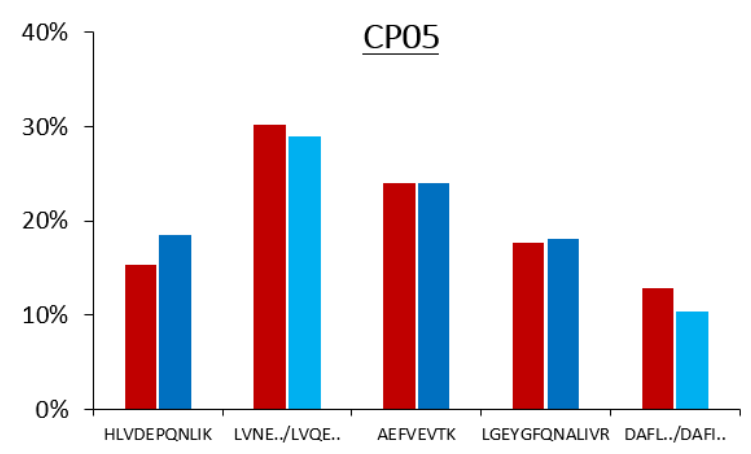

B

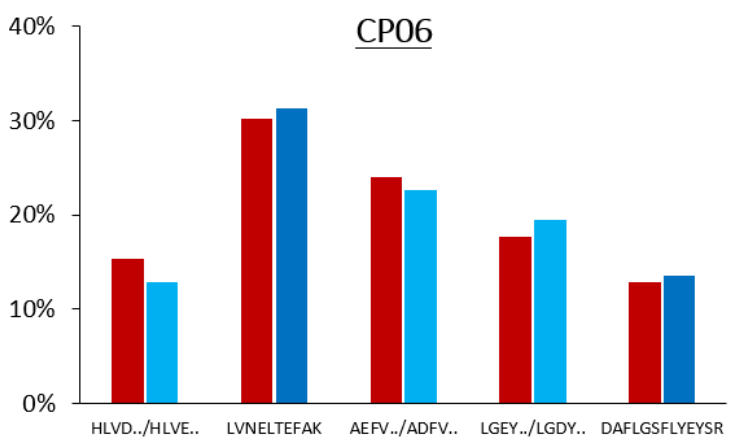

CP (scrambled)

Figure S6. Matching R-peptides relative peak areas for BSA (native) and both CP05 (A) and CP06 (B) obtained using Top6(y,b) fragment ions. Differences were $<5 \%$ for all pairs. 

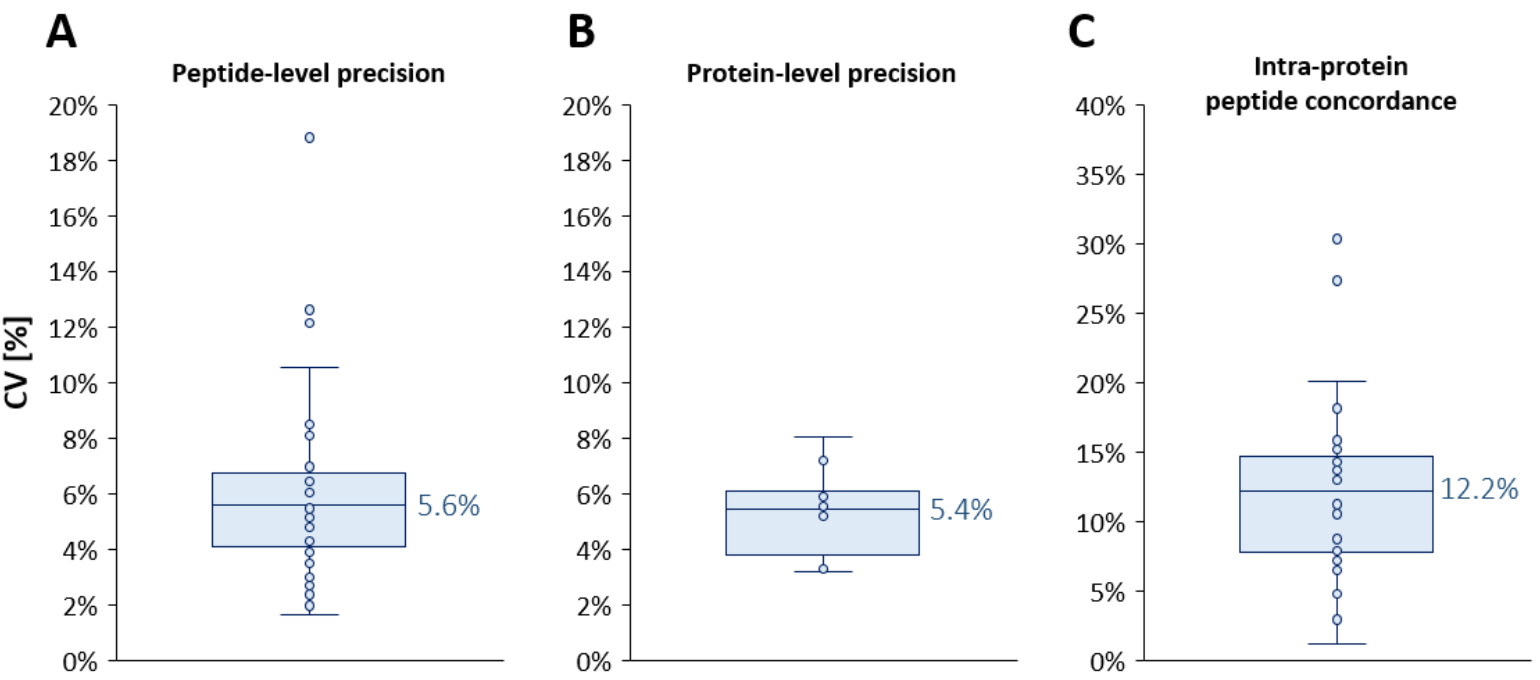

Figure S7. Precision of FastCAT method obtained from the PRM analysis of the pooled CSF sample. Panels A and B show peptide-level and protein-level precision, respectively. The graphs are created with data acquired for all investigated proteins (10 target proteins and two CPs) based on three sample preparation replicates and two LC injections each. Panel C shows intra-protein peptide concordance obtained from the same data set. Median CV values are given on the graphs. Each box plot displays the median (line), the 25th and 75th percentiles (box), and the 5th and 95th percentiles (whiskers). 


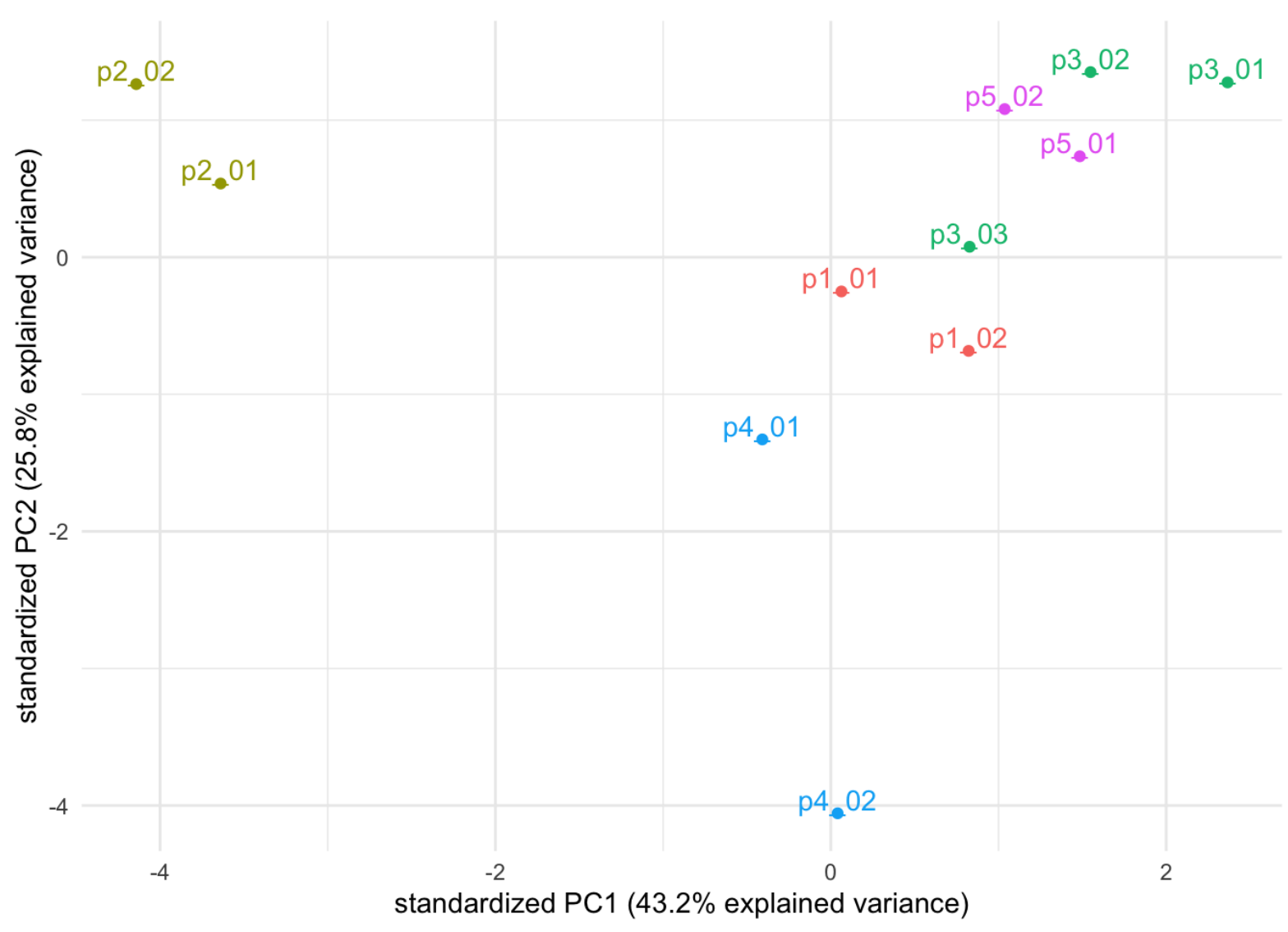

Figure S8. Principal component analysis (PCA) graph for all quantitative data (from Table S4) obtained for patients 1-5 (p1-p5) with two (or 3 for p3) times of sample collection. 
Table S1. List of the representative E. coli proteins (selected from those of the highest abundance) used for an estimation of the amount of an extra E. coli background introduced with non-purified CP standard, together with their UniProt accession numbers, as well as the peptides (three per protein) with their retention times and charge states. Peptides were selected to be free of missed cleavages, not containing cysteine and methionine and represented by the clearly dominant one charge state.

\begin{tabular}{|c|c|c|c|c|}
\hline Protein & $\begin{array}{c}\text { UniProt } \\
\text { Accession }\end{array}$ & Peptide & RT & $\begin{array}{c}\text { Charge } \\
\text { state }\end{array}$ \\
\hline \multirow[t]{3}{*}{ DNA-directed RNA polymerase } & P0A8V2 & LIEVPVEYIAGK & 76.7 & 2 \\
\hline & & GSWLDFEFDPK & 87.1 & 2 \\
\hline & & LGDLPTSGQIR & 57.5 & 2 \\
\hline \multirow[t]{3}{*}{ Elongation factor Ts } & P0A6P1 & IGVLVAAK & 53.2 & 2 \\
\hline & & AEITASLVK & 55.2 & 2 \\
\hline & & EHNAEVTGFIR & 53.7 & 3 \\
\hline \multirow{3}{*}{ 50S ribosomal protein $\mathrm{L} 4$} & P60723 & DATGIDPVSLIAFDK & 88.9 & 2 \\
\hline & & SILSELVR & 76.7 & 2 \\
\hline & & DAQSALTVSETTFGR & 69.9 & 2 \\
\hline \multirow[t]{3}{*}{ Pyruvate dehydrogenase E1 } & P0AFG8 & LVPIIADEAR & 64.4 & 2 \\
\hline & & AQYLIDQLLAEAR & 89.5 & 2 \\
\hline & & DWLQAIESVIR & 105.7 & 2 \\
\hline \multirow[t]{3}{*}{ 50S ribosomal protein L1 } & P0A7L0 & VGTVTPNVAEAVK & 56.0 & 2 \\
\hline & & QYDINEAIALLK & 85.9 & 2 \\
\hline & & GATVLPHGTGR & 41.1 & 2 \\
\hline \multirow[t]{3}{*}{ 30S ribosomal protein $\mathrm{S} 1$} & P0AG67 & AYEDAETVTGVINGK & 64.3 & 2 \\
\hline & & GGFTVELNGIR & 70.9 & 2 \\
\hline & & SESAIPAEQFK & 55.2 & 2 \\
\hline \multirow[t]{3}{*}{$\overline{\text { Elongation factor } \mathrm{G}}$} & P0A6M8 & IATDPFVGNLTFFR & 89.9 & 2 \\
\hline & & VYSGVVNSGDTVLNSVK & 67.9 & 2 \\
\hline & & GGVIPGEYIPAVDK & 70.7 & 2 \\
\hline \multirow{3}{*}{ 30S ribosomal protein $\mathrm{S} 2$} & P0A7V0 & VHIINLEK & 51.9 & 2 \\
\hline & & LENSLGGIK & 51.7 & 2 \\
\hline & & DAALSCDQFFVNHR & 66.1 & 3 \\
\hline \multirow{3}{*}{$\overline{\text { Elongation factor Tu1 }}$} & P0CE47 & TTLTAAITTVLAK & 82.1 & 2 \\
\hline & & AGENVGVLLR & 61.4 & 2 \\
\hline & & ILELAGFLDSYIPEPER & 98.4 & 2 \\
\hline
\end{tabular}


Table S2. Relative error of the CP05/06 quantification based on the scrambled R-peptides and using either MS1-derived (DDA) peptides peak areas or different MS2 fragment ions (PRM).

\begin{tabular}{|c|c|c|c|c|c|c|c|c|c|c|c|c|c|}
\hline \multirow{3}{*}{$\begin{array}{l}\text { Native } \\
\text { form }\end{array}$} & \multirow{3}{*}{$\begin{array}{l}\text { Scrambled } \\
\text { form in } \mathrm{CP}\end{array}$} & \multirow{3}{*}{$\begin{array}{l}\Delta \Delta \mathbf{R T} \\
{[\mathrm{min}]}\end{array}$} & \multirow{3}{*}{$\begin{array}{c}\text { CP with } \\
\text { scrambled } \\
\text { form }\end{array}$} & \multicolumn{3}{|c|}{ MS1-based (DDA) } & \multicolumn{7}{|c|}{ MS2-based (PRM) } \\
\hline & & & & \multirow[t]{2}{*}{$\begin{array}{c}\mathrm{CP}[\mathrm{fmol}] \\
\text { by nat }\end{array}$} & \multirow[t]{2}{*}{$\begin{array}{l}\mathrm{CP}[\mathrm{fmol}] \\
\text { by scr }\end{array}$} & \multirow[t]{2}{*}{$\begin{array}{c}\% \\
\text { error }\end{array}$} & \multirow[t]{2}{*}{$\begin{array}{c}\mathrm{CP}[\mathrm{fmol}] \\
\text { by nat }\end{array}$} & \multicolumn{6}{|c|}{$\begin{array}{c}\mathrm{CP}[\mathrm{fmol}] \\
\text { by scr }\end{array}$} \\
\hline & & & & & & & & Top1 & $\%$ error & Top3(y) & $\%$ error & Top6(y,b) & $\%$ error \\
\hline HLVDEPQNLIK & HLVEEPNQLIK & 2.5 & CP06 & 275 & 290 & $5.4 \%$ & 294 & 241 & $17.9 \%$ & 241 & $17.7 \%$ & 236 & $19.7 \%$ \\
\hline LVNELTEFAK & LVQETLEFAK & 5.4 & $\mathrm{CP} 05$ & 270 & 295 & $9.0 \%$ & 280 & 180 & $35.8 \%$ & 245 & $12.5 \%$ & 250 & $10.9 \%$ \\
\hline AEFVEVTK & ADFVETVK & 1.2 & CP06 & 275 & 274 & $0.4 \%$ & 294 & 185 & $36.9 \%$ & 268 & $8.7 \%$ & 265 & $9.7 \%$ \\
\hline LGEYGFQNALIVR & 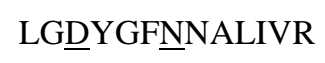 & 1.1 & CP06 & 275 & 312 & $13.4 \%$ & 294 & 329 & $12.1 \%$ & 341 & $16.4 \%$ & 310 & $5.4 \%$ \\
\hline DAFLGSFLYEYSR & DAFIGTFLYEYSR & 0.5 & $\mathrm{CP} 05$ & 270 & 188 & $31.0 \%$ & 280 & 214 & $23.9 \%$ & 203 & $27.4 \%$ & 211 & $24.7 \%$ \\
\hline
\end{tabular}


Table S3. Protein concentrations (ng/mL) detected in 11 CSF samples from 5 individual patients with multiple sclerosis. CSF was collected two times for four patients and three times for the patient 3 . Patient age at $1^{\text {st }}$ collection is given in years $(y)$, while the time difference $(\Delta t)$ to the $2^{\text {nd }}$ (and $3^{\text {rd }}$ for patient 3 ) puncture is given in months $(\mathrm{m})$.

\begin{tabular}{|c|c|c|c|c|c|c|c|c|c|c|c|}
\hline \multirow{4}{*}{ Protein } & \multicolumn{11}{|c|}{ Concentration in CSF [ng/mL] } \\
\hline & \multicolumn{2}{|c|}{ Patient 1} & \multicolumn{2}{|c|}{ Patient 2} & \multicolumn{3}{|c|}{ Patient 3} & \multicolumn{2}{|c|}{ Patient 4} & \multicolumn{2}{|c|}{ Patient 5} \\
\hline & time 1 & time 2 & time 1 & time 2 & time 1 & time 2 & time 3 & time 1 & time 2 & time 1 & time 2 \\
\hline & age, $43 \mathrm{y}$ & $\Delta \mathrm{t}, 40 \mathrm{~m}$ & age, $61 \mathrm{y}$ & $\Delta \mathrm{t}, 17 \mathrm{~m}$ & age, 36 & $\Delta \mathrm{t}, 10 \mathrm{~m}$ & $\Delta \mathrm{t}, 16 \mathrm{~m}$ & age, $30 \mathrm{y}$ & $\Delta \mathrm{t}, 32 \mathrm{~m}$ & age, $30 \mathrm{y}$ & $\Delta \mathrm{t}, 26 \mathrm{~m}$ \\
\hline APOE & 1489.28 & 1604.15 & 1106.19 & 922.07 & 1926.15 & 1807.81 & 1772.67 & 1854.96 & 2075.59 & 1996.34 & 1811.10 \\
\hline APOD & 1197.68 & 1307.78 & 1185.15 & 1203.23 & 1284.59 & 1281.67 & 1297.31 & 1083.58 & 1060.41 & 1246.55 & 1327.29 \\
\hline $\mathbf{A A C T}$ & 759.84 & 684.61 & 765.58 & 723.96 & 580.30 & 564.96 & 770.17 & 810.35 & 1127.28 & 540.90 & 588.94 \\
\hline ZAG & 100.05 & 113.18 & 102.01 & 96.32 & 85.98 & 85.89 & 87.58 & 102.12 & 108.05 & 85.19 & 85.76 \\
\hline SCG1 & 636.56 & 684.09 & 451.77 & 388.55 & 942.32 & 885.69 & 869.22 & 788.86 & 862.85 & 852.69 & 850.08 \\
\hline LRG1 & 67.98 & 71.42 & 77.14 & 80.84 & 50.02 & 47.78 & 114.29 & 38.45 & 92.91 & 27.13 & 33.82 \\
\hline CH3L1 & 51.77 & 35.09 & 35.16 & 33.37 & 53.82 & 49.85 & 44.63 & 38.90 & 27.48 & 27.90 & 25.74 \\
\hline CNTN1 & 238.90 & 256.07 & 159.70 & 148.28 & 229.68 & 230.81 & 229.77 & 241.20 & 268.62 & 257.04 & 246.15 \\
\hline VGF & 139.34 & 163.29 & 62.64 & 60.65 & 175.94 & 133.49 & 141.99 & 73.35 & 98.14 & 110.97 & 99.89 \\
\hline NPTX1 & 75.67 & 86.02 & 42.50 & 37.18 & 77.01 & 72.52 & 71.98 & 64.28 & 81.85 & 70.87 & 68.53 \\
\hline
\end{tabular}


Table S4. All chimeric protein (CP) standards used in the study, together with the information on their molecular weights, labeling efficiencies as well as amino acid sequences.

\begin{tabular}{|c|c|c|c|}
\hline $\begin{array}{c}\text { Chimeric } \\
\text { Protein }\end{array}$ & $\begin{array}{c}\text { Molecular } \\
\text { weight }\end{array}$ & $\begin{array}{l}\text { Labeling } \\
\text { efficiency }\end{array}$ & Amino acid sequence \\
\hline CP01 & $264.8 \mathrm{kDa}$ & $>99 \%$ & 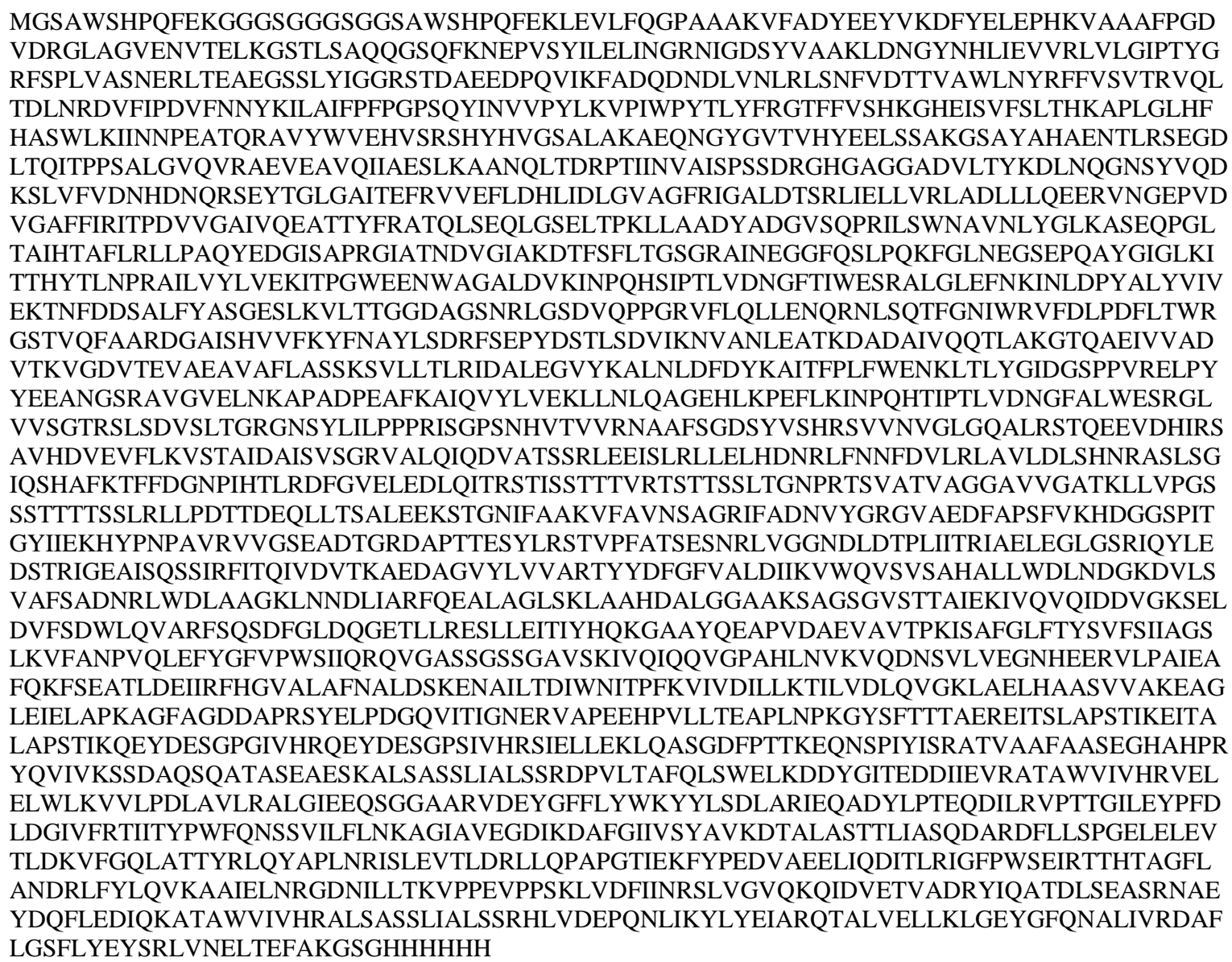 \\
\hline
\end{tabular}




\begin{tabular}{|c|c|c|c|}
\hline CP02 & $79.3 \mathrm{kDa}$ & $>99 \%$ & $\begin{array}{l}\text { MGSAWSHPQFEKGGGSGGGSGGSAWSHPQFEKLEVLFQGPAAAKVFADYEEYVKDFYELEPHKVAAAFPGD } \\
\text { VDRGLAGVENVTELKLGDYGFNNALIVRDAFIGTFLYEYSRAAAYVLQETPVVNALVDENEIVYRSDGEVEIA } \\
\text { SEKVIDTAYEIIKGIILIGEGIGNAEEQAAEFLKVQNDDSIVFFDYRVLEATLAQDFSKLVTWYDNEFGYTNRYA } \\
\text { GEDAAAGAAETLFVAKAEIEAVQIIAETLKVVEFLEHILDLGVAGFRIVQVNLDDVGKVGDVTEVAEAAVFLA } \\
\text { TSKAGLAIEGDIKANEILSDIWNITPFKGIAEDFAPTFVKIADLEGIYKALQLDFEYKALVFETWQGPLEVRWVAI } \\
\text { DGEQYGEGSSRLIDDNVANALKVVDHAYEAVVIGAGGAGLRLYDVARFHGATSINLVGDLDTVTNPKGTVA } \\
\text { HDGDYLIVAKTVEADAAHGSVTRTIEADAAHGSVTRVVELITYIATKYAVFDTGSRVTENVLAFIYKQLLFSAG } \\
\text { AELNKLDLGTVVSPVSGPKLGANTLLELVIFGRAFGGNTQDFGRVFQFLEASAGSKLNADTSLFILASKGQETST } \\
\text { QPIATIFAWSRAGQSHLGLPIFGSAVEAKGVEPSHAISGARALIANGTGPYFYLPKNTVIASGGYGRAAAAQINY } \\
\text { IRSGNVVPGYHGAVLRVALLGAGAGIGNPLGLLLKVPQVILAVGLPARHLVEEPNQLIKLVNELTEFAKGSGHH } \\
\text { HHHH }\end{array}$ \\
\hline CP03 & $42.3 \mathrm{kDa}$ & $>99 \%$ & $\begin{array}{l}\text { MGSAWSHPQFEKGGGSGGGSGGSAWSHPQFEKLEVLFQGPAAAKVFADYEEYVKDFYELEPHKVAAAFPGD } \\
\text { VDRGLAGVENVTELKIGEEYISDLDQLRVIFLENYRLLSYVDDEAFIRVLVDLERTLSDYNIQKESTLHLVLRTIT } \\
\text { LEVEPSDTIENVKEGIPPDQQRIGDYAGIKVLGIDGGEGKEALDFFARVVGLSTLPEIYEKANELLINVKGVIFYE } \\
\text { SHGKGNPTVEVELTTEKTFAEALRAADALLLKTAGIQIVADDLTVTNPKNVNDVIAPAFVKVNQIGTLSESIKA } \\
\text { VDDFLISLDGTANKHLVDEPQNLIKYLYEIARQTALVELLKLGEYGFQNALIVRDAFLGSFLYEYSRLVNELTEF } \\
\text { AKGSGHHHHHH }\end{array}$ \\
\hline CP04 & $43.0 \mathrm{kDa}$ & $>99 \%$ & $\begin{array}{l}\text { MGSAWSHPQFEKGGGSGGGSGGSAWSHPQFEKLEVLFQGPAAAKVFADYEEYVKDFYELEPHKVAAAFPGD } \\
\text { VDRGLAGVENVTELKHLVDEPQNLIKLVNELTEFAKIGEEYISDLDQLRVIFLENYRLLSYVDDEAFIRVLVDLE } \\
\text { RTLSDYNIQKESTLHLVLRTITLEVEPSDTIENVKEGIPPDQQRYLYEIARLVTDLTKAEFVEVTKIGDYAGIKVL } \\
\text { GIDGGEGKEALDFFARVVGLSTLPEIYEKANELLINVKGVIFYESHGKGNPTVEVELTTEKTFAEALRAADALLL } \\
\text { KTAGIQIVADDLTVTNPKNVNDVIAPAFVKVNQIGTLSESIKAVDDFLISLDGTANKLGEYGFQNALIVRDAFLG } \\
\text { SFLYEYSRGSGHHHHHH }\end{array}$ \\
\hline CP05 & $45.4 \mathrm{kDa}$ & $>99 \%$ & $\begin{array}{l}\text { MGSAWSHPQFEKGGGSGGGSGGSAWSHPQFEKLEVLFQGPAAAKVFADYEEYVKDFYELEPHKVAAAFPGD } \\
\text { VDRGLAGVENVTELKHLVDEPQNLIKLVQETLEFAKSELEEQLTPVAEETRLGPLVEQGRAATVGSLAGQPLQ } \\
\text { ERQWAGLVEKLAVYQAGARNILTSNNIDVKIPTTFENGRNPNLPPETVDSLKVLNQELRWYEIEKAEFVEVTKI } \\
\text { TLLSALVETRNLAVSQVVHKAVLDVFEEGTEASAATAVKADLSGITGARHVEDVPAFQALGSLNDLQFFRYSL } \\
\text { TYIYTGLSKEIPAWVPFDPAAQITKQKWEAEPVYVQRNYPSLELDKNYLNYGEEGAPGKGEAGAPGEEDIQGP } \\
\text { TKWQQQGDLQDTKLGEYGFQNALIVRDAFIGTFLYEYSRGSGHHHHHH }\end{array}$ \\
\hline СР06 & $46.0 \mathrm{kDa}$ & $>99 \%$ & $\begin{array}{l}\text { MGSAWSHPQFEKGGGSGGGSGGSAWSHPQFEKLEVLFQGPAAAKVFADYEEYVKDFYELEPHKVAAAFPGD } \\
\text { VDRGLAGVENVTELKHLVEEPNQLIKLVNELTEFAKVAAGAFQGLRGQTLLAVAKTLDLGENQLETLPPDLLR } \\
\text { ENQLEVLEVSWLHGLKFPLTNAIKILGQQVPYATKTLLSVGGWNFGSQRVTIDSSYDIAKGNQWVGYDDQESV } \\
\text { KADFVETVKFIPLIPIPERASPFPVYKTDGAAPNVAPSDVGGGGGRVQVTSQEYSARNSEPQDEGELFQGVDPRT } \\
\text { HLGEALAPLSKLADLASDLLLQYLLQGGARVGEEDEEAAEAEAEAEEAERFQLTFPLRTPAAETLSQLGQTLQS } \\
\text { LKALSGNVIAWAESHIEIYGGATKLGDYGFNNALIVRDAFLGSFLYEYSRGSGHHHHHH }\end{array}$ \\
\hline
\end{tabular}

